Invited review article

\title{
Continental-scale patterns and climatic drivers of fruiting phenology: A quantitative Neotropical review
}

\author{
Irene Mendoza ${ }^{\mathrm{a}, *}$, Carlos A. Peres ${ }^{\mathrm{b}}$, Leonor Patrícia C. Morellato ${ }^{\mathrm{a}}$ \\ a Universidade Estadual Paulista, Departamento de Botânica, Laboratório de Fenologia, Av. 24A, 1515, 13506-900 Rio Claro, SP, Brazil \\ b School of Environmental Sciences, University of East Anglia, Norwich NR4 7TJ, United Kingdom
}

\section{A R T I C L E I N F O}

\section{Article history:}

Received 2 July 2016

Received in revised form 5 December 2016

Accepted 7 December 2016

Available online 9 December 2016

\section{Keywords:}

Fruit and seed production

America

Frugivore

Climate change

Tropics

\begin{abstract}
A B S T R A C T
Changes in the life cycle of organisms (i.e. phenology) are one of the most widely used early-warning indicators of climate change, yet this remains poorly understood throughout the tropics. We exhaustively reviewed any published and unpublished study on fruiting phenology carried out at the community level in the American tropics and subtropics (latitudinal range: $26^{\circ} \mathrm{N}-26^{\circ} \mathrm{S}$ ) to (1) provide a comprehensive overview of the current status of fruiting phenology research throughout the Neotropics; (2) unravel the climatic factors that have been widely reported as drivers of fruiting phenology; and (3) provide a preliminary assessment of the potential phenological responses of plants under future climatic scenarios. Despite the large number of phenological datasets uncovered (218), our review shows that their geographic distribution is very uneven and insufficient for the large surface of the Neotropics $\left(\sim 1\right.$ dataset per $\left.\sim 78,000 \mathrm{~km}^{2}\right)$. Phenological research is concentrated in few areas with many studies (state of São Paulo, Brazil, and Costa Rica), whereas vast regions elsewhere are entirely unstudied. Sampling effort in fruiting phenology studies was generally low: the majority of datasets targeted fewer than 100 plant species (71\%), lasted 2 years or less (72\%), and only $10.4 \%$ monitored $>15$ individuals per species. We uncovered only 10 sites with ten or more years of phenological monitoring. The ratio of numbers of species sampled to overall estimates of plant species richness was wholly insufficient for highly diverse vegetation types such as tropical rainforest, seasonal forest and cerrado, and only slightly more robust for less diverse vegetation types, such as deserts, arid shrublands and open grassy savannas. Most plausible drivers of phenology extracted from these datasets were environmental (78.5\%), whereas biotic drivers were rare (6\%). Among climatic factors, rainfall was explicitly included in $73.4 \%$ of cases, followed by air temperature (19.3\%). Other environmental cues such as water level (6\%), solar radiation or photoperiod (3.2\%), and ENSO events (1.4\%) were rarely addressed. In addition, drivers were analyzed statistically in only $38 \%$ of datasets and techniques were basically correlative, with only $4.8 \%$ of studies including any consideration of the inherently autocorrelated character of phenological time series. Fruiting peaks were significantly more often reported during the rainy season both in rainforests and cerrado woodlands, which is at odds with the relatively aseasonal character of the former vegetation type. Given that climatic models predict harsh future conditions for the tropics, we urgently need to determine the magnitude of changes in plant reproductive phenology and distinguish those from cyclical oscillations. Longterm monitoring and herbarium data are therefore key for detecting these trends. Our review shows that the unevenness in geographic distribution of studies, and diversity of sampling methods, vegetation types, and research motivation hinder the emergence of clear general phenological patterns and drivers for the Neotropics. We therefore call for prioritizing research in unexplored areas, and improving the quantitative component and statistical design of reproductive phenology studies to enhance our predictions of climate change impacts on tropical plants and animals.
\end{abstract}

(c) 2016 Elsevier B.V. All rights reserved.

\section{Contents}

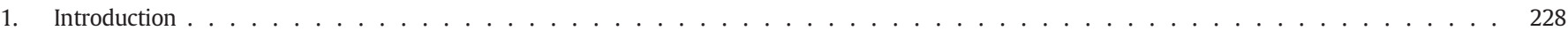

2. Current status of Neotropical phenological studies . . . . . . . . . . . . . . . . . . . . . . . . . . . . . . . 229

\footnotetext{
* Corresponding author.

E-mail address: irene.mendoza.sagrera@gmail.com (I. Mendoza).
} 
2.1. Historic background of phenological research and its increasing importance . . . . . . . . . . . . . . . . . . . . . . 229

2.2. Review methodology: selection criteria for literature survey . . . . . . . . . . . . . . . . . . . . . . . . . . . . . . . . 229

2.3. Geographic distribution of phenological research . . . . . . . . . . . . . . . . . . . . . . . . . . . . 231

2.4. Sampling effort: number of stems and species sampled, monitoring length and frequency of phenological observations. . . . . . . . . . . 231

2.5. Sampling techniques . . . . . . . . . . . . . . . . . . . . . . . . . . . 231

2.6. Plant habits and vegetation types sampled . . . . . . . . . . . . . . . . . . . . . . . . . . . 233

3. Environmental drivers of fruiting phenology across the Neotropics . . . . . . . . . . . . . . . . . . . . . . . . 235

4. Future climate changes and their impact on fruiting phenology . . . . . . . . . . . . . . . . . . . . . . . . . . . . . . 237

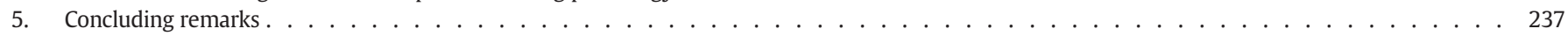

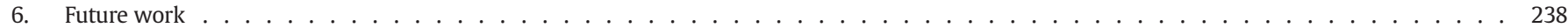

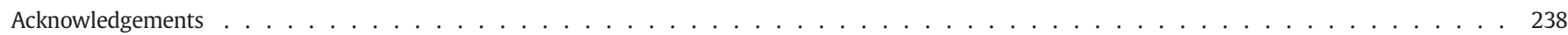

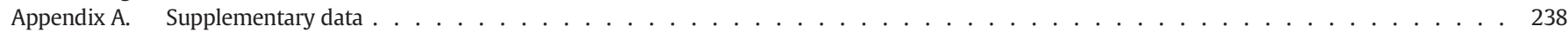

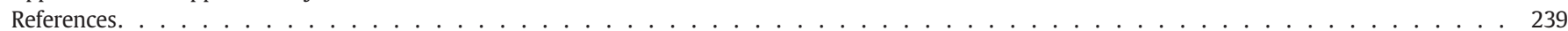

\section{Introduction}

Phenological shifts are one of the most widely used early-warning indicators of climate change (IPCC, 2014; Menzel et al., 2006; Parmesan and Yohe, 2003; Primack et al., 2009; Root et al., 2003), because the timing of life-cycle events is finely tuned to climate (Cleland et al., 2007). Numerous studies have shown systematic changes in the vegetative and reproductive schedules of organisms as a consequence of rising temperatures (Chambers et al., 2013; IPCC, 2014; Rosenzweig et al., 2008). For instance, there is a large body of evidence from the Northern Hemisphere that many plant species tend to bloom earlier in springtime (Gordo and Sanz, 2010; Parmesan, 2007; Primack et al., 2009; Schwartz et al., 2006; Xu et al., 2013), or drop their leaves later in autumn (Gallinat et al., 2015; Gill et al., 2015; Ibáñez et al., 2010), as a response to warmer temperatures. Other changes in the timing of migrations, diapause or breeding events have also been widely reported in animals (e.g. Both et al., 2006; Forrest, 2016; Parmesan, 2006, 2007; Primack et al., 2009).

Detecting the climatic drivers that control plant phenology is a central challenge in ecological research. Air temperature in particular (including winter chilling) has been signaled as the most critical environmental cue affecting plant life cycles, especially in highlatitude regions (Cook et al., 2012; Menzel et al., 2006). This explains the high confidence in the detection and attribution of advancements of plant growth and flowering to warming due to anthropogenic climate change (IPCC, 2014; Parmesan, 2007; Parmesan and Hanley, 2015). However, our relatively robust understanding of temperature-driven phenological changes results from the overwhelming dominance of research carried out in temperate, boreal and artic ecosystems of the Northern Hemisphere (Chambers et al., 2013). As such, drivers other than spring temperature (Gallinat et al., 2015), particularly in other study regions, have been severely neglected. In the tropics, temperature gradients are far subtler than in high-latitude climates, so plant seasonality has traditionally been explained in terms of rainfall patterns (Reich, 1995; van Schaik et al., 1993). Many tropical studies have therefore attempted to relate flower and fruit production to the alternation of dry and wet seasons, even if other environmental drivers may also be relevant. Among them, photoperiod (day length relative to night length) and the intensity of solar irradiation (i.e. daily insolation) may be among the most important, yet understudied, triggers of tropical plant phenology (Borchert et al., 2015; Calle et al., 2010; van Schaik et al., 1993). Although some workers have reviewed the main biotic and abiotic drivers affecting plant reproductive phenology (e.g. Chambers et al., 2013; Fenner, 1998; Rathcke and Lacey, 1985; Richardson et al., 2013; Rosenzweig et al., 2008), they offer little information on tropical organisms (but see van Schaik et al., 1993 as an exception). Recently, Morellato et al. (2013) provided a qualitative overview of plant phenology studies and perspectives in Central and South America, but a quantitative continental-scale review of phenological drivers remains conspicuously lacking throughout the tropics.
Our poor understanding of the climatic drivers of tropical phenology can be clearly linked to the overall paucity of long-term ecological monitoring (i.e. with at least 10 years of data, see Chambers et al., 2013 for the same criterion) in virtually all tropical countries (but see Alencar et al., 1979; Newstrom et al., 1994; Wright and Calderón, 2006 as exceptions for the Neotropics). In contrast, long-term time series of phenological data are relatively abundant for many temperate areas (e.g. Cook et al., 2012; Menzel et al., 2006; Schwartz and Reiter, 2000; Sparks and Menzel, 2002). In addition to short-term monitoring, the high species diversity in the tropics imposes major challenges because it is difficult to distinguish a single-species phenological trend from the overall community pattern if this species is rare or poorly sampled (Morellato et al., 2010; Newstrom et al., 1994; Sakai, 2001). Phenological cycles are extremely variable among taxa (Parmesan, 2007; Primack et al., 2009), so assemblage-wide phenological patterns become noisy when co-existing plant species display a broad array of background life-cycle modes, including annual, biannual or irregular flowering and fruiting (Newstrom et al., 1994; Sakai, 2001). Finally, standardized methods of phenological monitoring are severely lacking, rendering broad generalizations more difficult (Chapman et al., 1994; Morellato et al., 2010; Newstrom et al., 1994). For instance, methodological comparisons between seed traps, observations of individual trees and liana crowns in the forest canopy, and fruit counts have shown inherent differences in the timing of fruiting, even if the study area and monitoring time were the same (Chapman et al., 1992; Morellato et al., 2010; Stevenson et al., 1998; Zhang and Wang, 1995).

Here, we review all published and unpublished research that examined fruiting phenology throughout the Neotropics using a communitywide approach. We were originally interested in retrieving studies representative of the phenological patterns of different Neotropical vegetation types, so we discarded studies at the population level. First, this large dataset, consisting of 218 different sites derived from 177 studies, enabled a comprehensive overview of the current status of fruiting phenology research. We evaluated the geographic distribution and variation in sampling effort of studies in terms of number of species observed, duration of monitoring, sampling techniques and vegetation types. Second, we extracted for each study the environmental drivers correlated with fruiting patterns, to discuss the abiotic factors that have been widely reported to explain Neotropical fruiting phenology. Our final purpose in this review is to identify major gaps in our understanding of the environmental drivers of fruiting phenology, as well as future research needs. We focus on fruiting phenology because vertebrate and invertebrate consumers can alter their metabolism, dietary profile, local daily movements and long-distance migrations tracking fruit resource production (Morellato et al., 2016; Peres, 1994). Therefore, changes in fruiting patterns at the plant community level have major bottom-up consequences for biodiversity conservation and management (Morellato et al., 2016; Peres, 1994). Our geographic focus is justified because the Neotropics is the most species-rich region on Earth, resulting from a complex geomorphology and paleographic 
evolution (Antonelli and Sanmartin, 2011; Arroyo et al., 2010) and the presence of extensive wetlands (Amazon wetlands and the Pantanal, Fraser and Keddy, 2005) and large river basins with associated vegetation (Amazon, Paraná, Purus and Madeira, Arroyo et al., 2010). In addition, the African and Asian tropics have an even poorer tradition of phenological research (Chambers et al., 2013; Schwartz, 2013).

\section{Current status of Neotropical phenological studies}

\subsection{Historic background of phenological research and its increasing importance}

Observations on animal and plant life cycles date back to ancient times and are intimately linked to the development of agriculture (Hudson and Keatley, 2010; Schwartz, 2013). However, the term phenology (from the Greek $\varphi \alpha \iota \nu \omega$, which in English means "to show, to appear") was adopted for the first time in 1849 by Charles Morren to describe the periodic monitoring of plants in the Royal Botanic Garden of Brussels (Demarée and Rutishauser, 2009, 2011; Morren, 1849). In the Neotropics, phenological studies started much later, with the first records of flowering and fruiting undertaken by Davis and Richards (1933) in an evergreen forest of British Guiana. Other pioneer studies were those of Alvim (1964) in Brazil and Allen (1956) in Costa Rica (see Morellato et al., 2013 for a complete historical description of the phenological research in Central and South America). Since the origins of phenological research, the number of studies has exponentially increased. A simple web search using the term "phenolog*" in the Scopus ${ }^{\circledR}$ database for all type of available documents (which includes peer-reviewed journals, books and conference proceedings) shows 24,000 references between 1970 and 2015 (Fig. 1). The total output is smaller when we restricted the search to studies including the terms "phenology*" and "trop*" (1990), and further still when "fruit" was added to the query (454), but the trend over time was the same (Fig. 1). An exponential growth in publication rate of phenological studies (as shown by a least square fit to an exponential model, $\mathrm{R}^{2}=0.96$ ) is a common behavior for the fields of Ecology, Biometeorology or Evolution (Fig. 1) among others, particularly after 1995 (Gupta et al., 1997; Vinkler, 2010). Even so, this increased rate of publication also shows a burgeoning interest in phenological research, more recently motivated by its insights into climate change (Cleland et al., 2007; Parmesan, 2007; Ibáñez et al., 2010; Keatley and Hudson, 2010; Chambers et al., 2013; Richardson et al., 2013). However, as we shall see, the extraction of clear and general phenological patterns and drivers is hindered by the unevenness in the geographic distribution of study sites, diversity of sampling methods, vegetation types, and different research motivations.

\subsection{Review methodology: selection criteria for literature survey}

We conducted a comprehensive bibliographic research of any published and unpublished study on fruiting phenology that has been carried in the American tropics and subtropics from $26^{\circ} \mathrm{N}$ to $26^{\circ} \mathrm{S}$. Published studies were searched using the Web of Science $®$, but supplemented by other electronic databases, including Binabitrop, Google Scholar, NAL Catalog, Periódicos CAPES, Scielo, and Scopus®. Our search terms included "phenolog*", "fruit*", and the sequence of all Neotropical countries. We restricted our searches to studies published up to December 2013. We also included grey literature such as reports from nongovernmental organizations, governmental institutions, and unpublished MSc and PhD dissertations, which had been cited in other papers, detected using digital libraries of the main Latin American universities, or obtained via direct enquiry to the authors. Unpublished information was also obtained from two sources: (1) original datasets from studies in which the authors of this paper were involved; and (2) direct enquiry to authors who had carried out unpublished phenological studies as uncovered by mass emailing to lists of ecologists (in January 2014) and systematic reviews of all abstracts in the Association of Tropical Biology and Conservation (ATBC) meetings from 2003 to 2013. A strict set of criteria was followed to select any published or unpublished dataset on fruiting phenology (Morellato et al., 2013): (1) the study had a community-wide approach that included at least ten species of more than one taxonomic family per site; (2) the study spanned an inclusive period of at least 12 consecutive months of observations; and (3) the study had been carried out in native vegetation. These criteria were chosen given that our original purpose was to evaluate fruiting as key resources for frugivorous vertebrates. Therefore, we discarded population-level studies, those conducted for agricultural purposes, and those conducted over very short timespans. When different publications were available from the same locality (e.g. Barro Colorado 'Island, Panama and La Selva, Costa Rica), we included them independently. Similarly, if the same study examined phenological information from different vegetation types or habitats that were separately monitored, we included each as an independent case in our database (although they shared the same geographic coordinates in some cases: e.g. Opler et al., 1980; Morellato et al., 2000). We discarded studies exclusively focused on herbaceous species (3.6\% of initial list of studies) because they rarely provide resources for frugivores. For each combination of research work and site (hereafter, dataset) that fitted

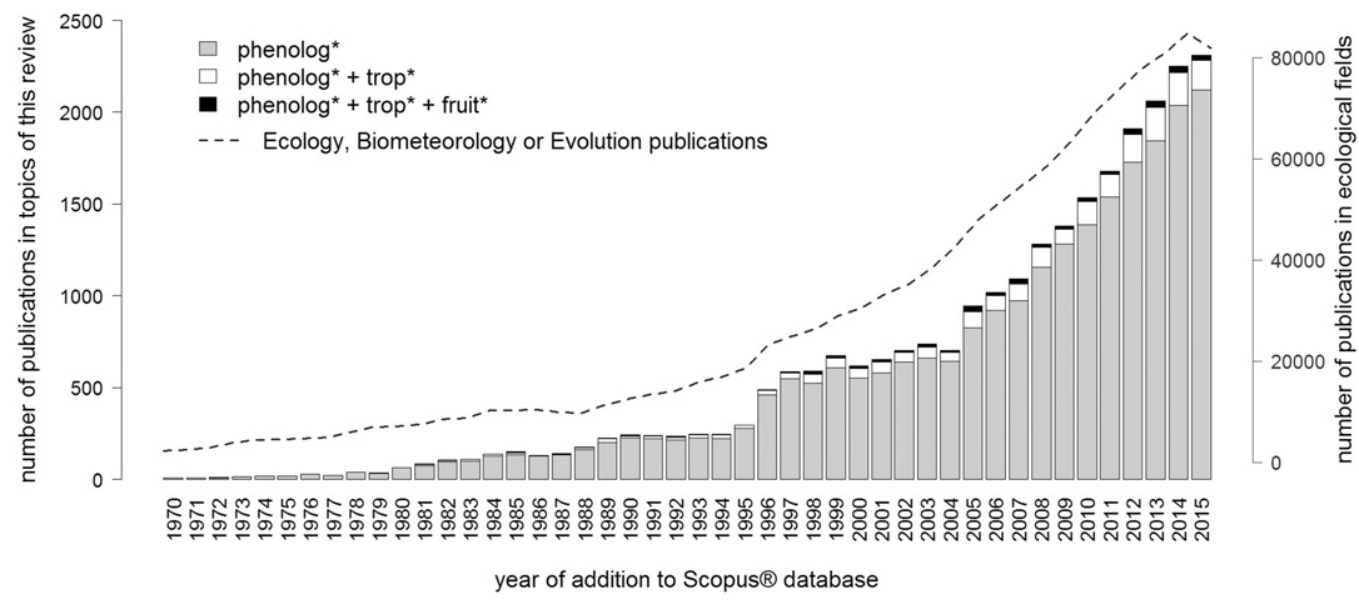

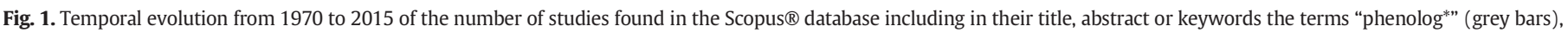

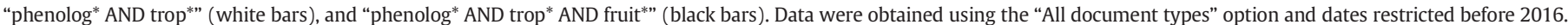

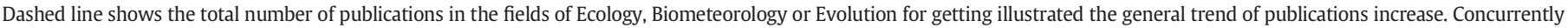

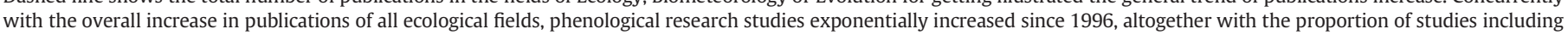
tropical and fruit information. 
A

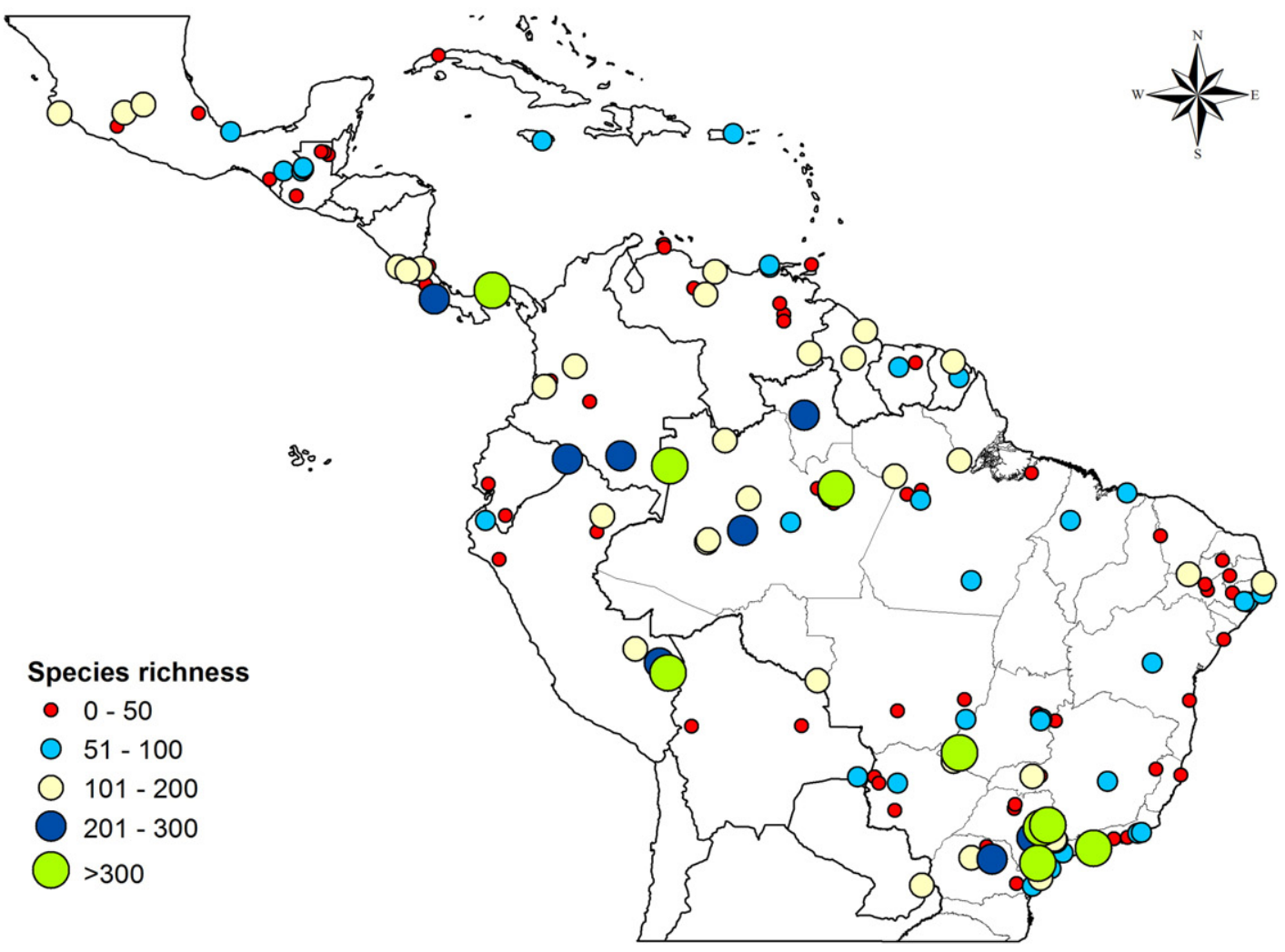

$\mathrm{B}$

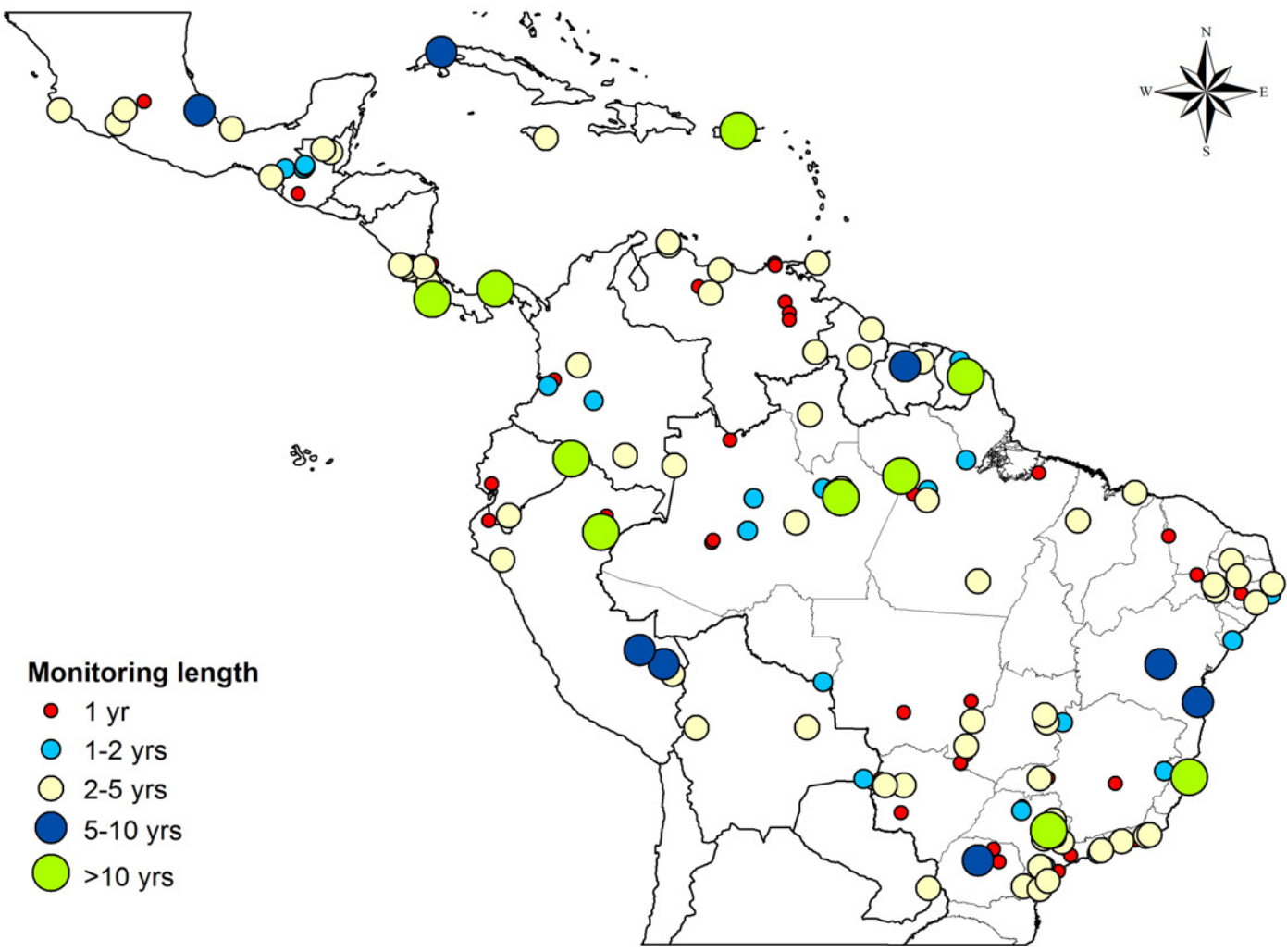

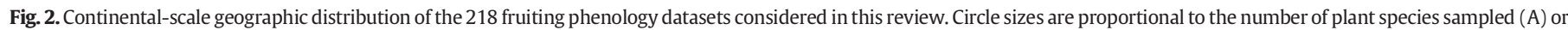
the study length in months (B). Some sites were represented by more than one study, hence the multiple circles.

the above list of criteria, we extracted the following items: bibliographic reference; locality as named in the study; exact location coordinates; duration of phenological monitoring (months); phenological sampling techniques (classified as direct observations with marked or unmarked individuals, litter traps, herbarium vouchers, seeds retrieved from faecal material), number of individuals, species and families monitored; life forms; and vegetation types. In order to understand the climatic influence on fruiting phenology, we first extracted from each dataset the 
assessed or inferred drivers of phenology, separating biotic from abiotic, which could include several environmental variables in the last case. Second, we noted whether any statistical analysis had been used to explore the relationship between environment and fruiting, and the sign of the statistical correlation when significant. Each dataset could include more than one environmental driver, and was added separately to our database. Third, we also recorded the time of year when the fruiting peak was described in relation to rainfall seasonality (dry, wet and transition seasons). Our entire R code used for data analyses and graphics are deposited in https://zenodo.org/badge/latestdoi/62281350. Data are available in a PANGEA repository.

\subsection{Geographic distribution of phenological research}

Our research uncovered a total of 218 fruiting phenology datasets across the Neotropics (Appendix 1), representing the largest literature survey compared to any other reviews on fruit phenology. For instance, Ting et al. (2008) and Hanya et al. (2013) reviewed 48 and 31 datasets at a global scale and Asian forests, respectively. However, this represents a very low density of studies for the large surface of the Neotropics ( 1 dataset per $\sim 78,000 \mathrm{~km}^{2}$ ).

The spatial distribution of Neotropical phenological studies surveyed was very uneven (Fig. 2). Some regions of South America such as the State of São Paulo in Brazil or Central Amazonia concentrated a large percentage of datasets (15.6\% and $7.3 \%$, respectively), whereas vast regions lack any phenological information, mainly in southern and western Amazonia, western Peru, and southern Bolivia (Fig. 2). Mesoamerican and Caribbean studies were represented by Panama, Costa Rica, Guatemala, Cuba and Puerto Rico. We were unable to find a single study from Belize, Honduras, El Salvador, or Nicaragua.

An analysis of the number of studies by country showed a highlyskewed J-shaped distribution, with an overwhelming dominance of research in Brazil compared to other countries (52.8\% of datasets; Fig. 3 ). This dominance cannot only be attributed to Brazil's vast territory, but also to the economic boom and large research investments allocated across the country over the last decade (Regalado, 2010). In particular, the high concentration of phenological studies in the state of São Paulo is facilitated by the São Paulo Research Foundation (FAPESP), the leading research funding agency across all Brazilian states (Catanzaro et al., 2014). In addition, two of the authors of this review have carried out two decades of phenological research in both the Atlantic Forest and cerrado scrublands of São Paulo and Brazilian Amazonia, further increasing the concentration of studies in these regions. Costa Rica is the second top-ranking country, with $9.4 \%$ of phenological datasets (Fig. 3). This again reflects high levels of research funding and support, as several North American institutions (such as the Organization for Tropical Studies and the Canadian Organization for Tropical

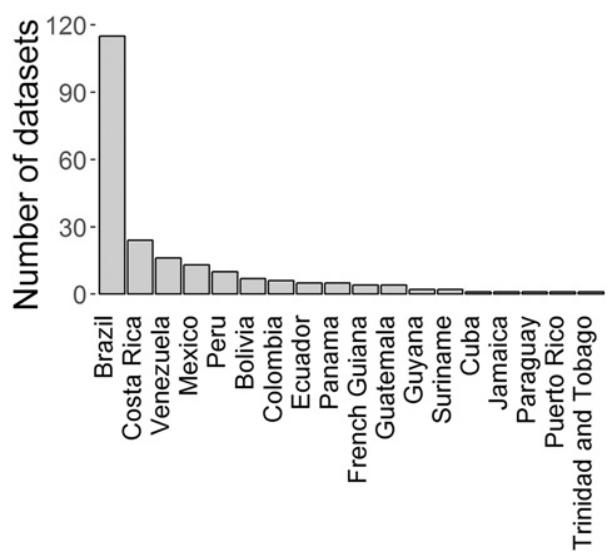

Fig. 3. Number of datasets per country included in this review; phenology studies spanned 18 Neotropical countries, with Brazil dominating research (52.8\%).
Education and Rainforest Conservation) have a long tradition of ecological research in Costa Rica. In the case of Panama, five studies were conducted at Barro Colorado Island (BCI; Fig. 2), whereas other areas in the country remain unsampled. The establishment of a field station on BCI by the Smithsonian Tropical Research Institute (STRI) in 1923 clearly boosted phenological research in that area, including some seminal studies (Croat, 1975) and others derived from the long-term monitoring program of flowering and fruiting phenology initiated in 1987 (Wright and Calderón, 2006).

2.4. Sampling effort: number of stems and species sampled, monitoring length and frequency of phenological observations

Not surprisingly, most datasets on fruiting phenology targeted between 10 and 100 plant species $(71 \%$; median $=64$; Fig. $2 \mathrm{~A})$, lasted only 24 months or less $(71.8 \%$, median $=18$ months; Fig. $2 \mathrm{~B}$ and Fig. S1), and monitored fewer than 1000 individual stems or vouchers (78.4\%, median $=400)$. In addition, only $10.4 \%$ of datasets sampled $>15$ individuals per species (Fig. S2), which would be the ideal minimum sample size for phenological studies at the community level (Morellato et al., 2010). Sampling effort in fruiting phenology studies was therefore generally low. Regarding the duration of observations, long-term monitoring was extremely rare right across the Neotropics, with only ten study sites with 10 or more years of phenological data (excluding studies using herbarium vouchers or bibliographic compilations; Fig. 2B): Barro Colorado Island, Panama, 1987 - present (Wright and Calderón, 2006; Zimmerman et al., 2007); El Verde, Puerto Rico, 1992 - present (Zimmerman et al., 2007); Península de Osa and Golfo Dulce, Costa Rica, 1989-2001 (Lobo et al., 2008); Nouragues Research Station, French Guiana, 2001-2011 (Mendoza et al. unpublished); Trombetas, Brazil, Central Amazon, 1978-1995 (Knowles and Parrotta, 1997); Jenaro Herrera Arboretum, Peru, 1974-1983 (Gautier and Spichiger, 1986); Yasuni National Park, Ecuador, 2000-present (Garwood et al. unpublished; Persson, 2005), and Linhares Nature Reserve, southeast Brazil, 1982-1992 (Engel and Martins, 2005); the Ducke Reserve near Manaus, Brazil, 1965-present, which is the longest long-term plant phenology study anywhere across the entire Neotropics (Alencar et al., 1979; Morellato et al., 2013), and the cerrado of Itirapina, São Paulo, Brazil, from 2004-present (Morellato et al., 2013).

There is a trade-off between sampling effort (in terms of number of species and individuals) and the frequency of phenological censuses (Hemingway and Overdorff, 1999; Morellato et al., 2010): low number of sampled individuals per species requires higher monitoring frequency to gain accuracy and resolution in describing phenological patterns (Morellato et al., 2010). When sample size is too low, weekly or fortnightly observations have been described as the most appropriate censusing frequency to distinguish phenophase peaks (Morellato et al., 2010), but this was rarely used in our database (6.3\% and $19.8 \%$ of datasets, respectively). In most studies, plants were monitored only once each month (61.3\%), which represents a compromise between logistical field work constraints and gaining detail in phenological information (Morellato et al., 2010). Monitoring once every two months or at more irregular intervals was only the case of a few datasets $(1.3 \%$ and $6.3 \%$, respectively). As nearly $90 \%$ of the studies we uncovered targeted fewer than 15 individuals per species (Fig. S2), monthly sampling may affect our insights into phenological patterns, especially in highly diverse vegetation types (see below) or communities dominated by species with fast fruit ripening, in which observers can overlook ephemeral fruit crops.

\subsection{Sampling techniques}

Fruiting phenology studies have been designed for different purposes and, therefore, sampling methods are highly divergent. Works range from purely descriptive studies that may relate climatic seasonality to fruit production (e.g. Croat, 1975), compare phenological patterns 


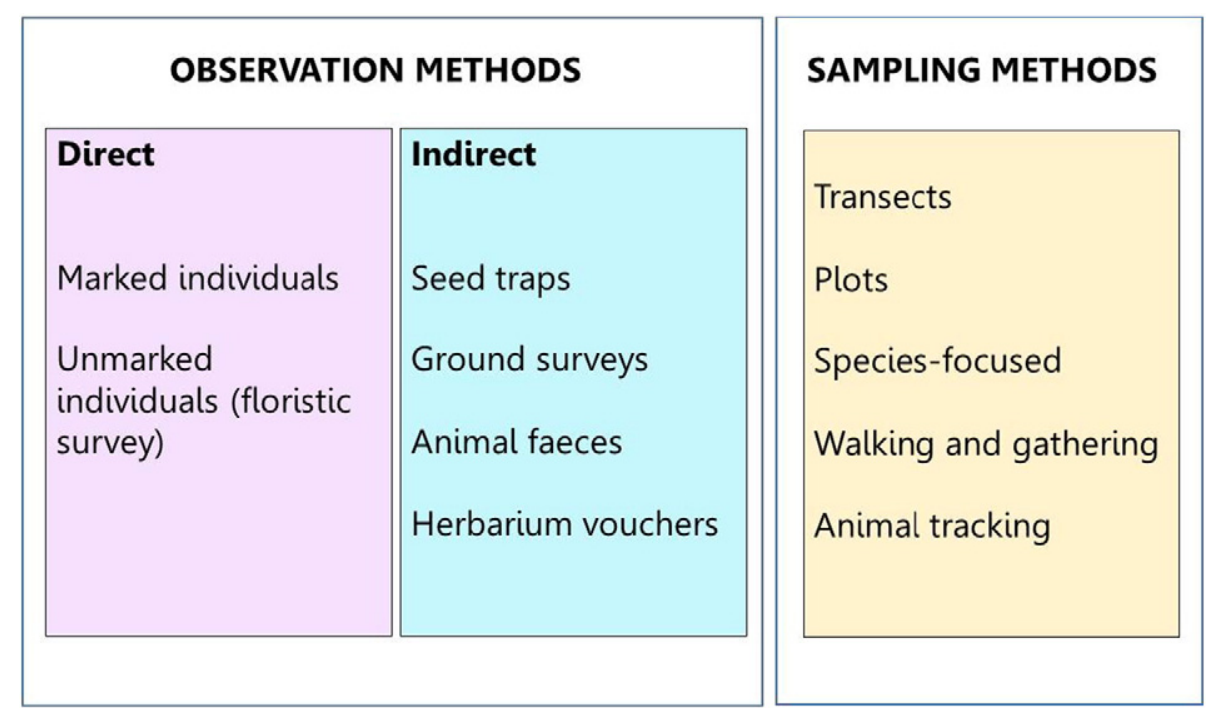

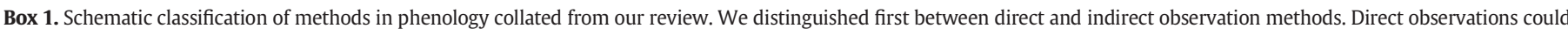

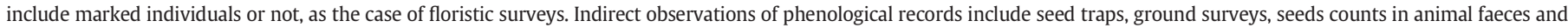

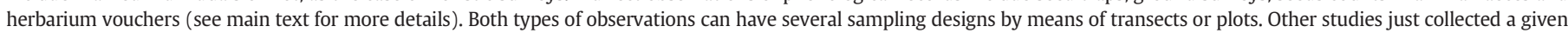
number of individuals of selected species or did the "walking-and-gathering" method. A few studies noted the fruit presence/absence of trees visited by animals, generally monkeys.

across different habitats (e.g. Frankie et al., 1974; Morellato et al., 2000), or address inter-annual variability in fruiting in relation to climatic events such El Niño Southern Oscillation (ENSO, e.g. Wright and Calderón, 2006). An additional major motivation to undertake fruiting phenology studies is to understand temporal patterns of food resource availability for frugivores and vertebrate seed dispersers, including birds (e.g. Develey and Peres, 2000; Wheelwright, 1986), bats (Estrada and Coates Estrada, 2001), primates (Boubli, 1997; Palminteri et al., 2012; Peres, 1994) and fish species (Kubitzki and Ziburski, 1994; Reys et al., 2005).

Given the wide spectrum of ecological studies based on fruiting phenology, several sampling techniques have been used (Archibold, 1994; Blake et al., 1990; Hemingway and Overdorff, 1999; Morellato et al., 2010). We distinguished first between direct and indirect observation methods (Box 1). Among direct approaches, the simplest and most widely applied technique (77\% of datasets; Fig. 4) is based on observations of focal crowns of previously marked individual plants. Observers then record the presence or absence of fruits of each marked stem, or alternatively use a rank-abundance index of any particular phenophase (d'Eça-Neves and Morellato, 2004; Fournier, 1974; Morellato et al., 2010). Studies focused on frugivore feeding ecology frequently include fruit counts within a tree (or woody liana) crown with the aid of binoculars (e.g. Palminteri et al., 2012). Other studies multiply the Fournier score (from 0 to 4; Fournier, 1974) of each stem by its basal area to derive a Fruit Availability Index (e.g. Hawes and Peres, 2016; Peres, 1994). However, direct observation can be done on unmarked individuals,

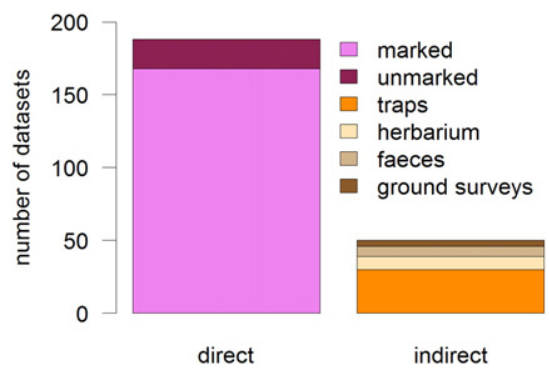

Fig. 4. Frequency of datasets according to the most common observational methods used to quantify fruiting phenology: direct observations (including marked or unmarked individuals) and indirect methods (seed traps, herbarium vouchers, seeds found in animal faeces, and ground surveys of fruit counts). generally as a consequence of systematic floristic surveys (Box 1), although this approach is rarely used (9.2\%, Fig. 4). This technique consists of regular collections or observations of reproductive plant parts, typically following pre-established trails or plots, along which the phenological status of unmarked individuals of species is noted (e.g. Batalha and Martins, 2004; Sabatier, 1985). Unlike observations based on marked individuals, the information derived from these surveys is restricted to presence/absence of fruits of each species, rather than quantitative estimates of fruit production.

Phenology can also be estimated from indirect observations, and we detected four main types (Box 1): seed traps, ground surveys, monitoring of seeds contained in animal faeces, and herbarium vouchers. Seedrain traps were the most common among indirect methods ( $13.8 \%$ of all datasets, Fig. 4; e.g. Mendoza et al., 2015; Wright and Calderón, 2006). These generally consist of regularly placed square frames (individual sampling trap surface across all studies $=0.66 \pm 0.6 \mathrm{~m}^{2}$; mean $\pm \mathrm{sd}$ ) containing a fine mesh. The number of traps is also highly variable among studies, ranging from 25 to 300 (113.3 \pm 71.4 ). Seed trapping is a preferred technique for studies focusing on quantitative fruit production (e.g. biomass) per unit area, although it has several caveats. For instance, fruit traps actually measure the residual fruit production once the fraction of fruits consumed by arboreal animals has been subtracted (Blake et al., 1990; Terborgh, 1983). Thus, estimates of edible fruits are biased during the low productivity season, in which frugivores are likely to eat a higher proportion of available fruits than when the fruit is superabundant (Terborgh, 1983). This can alter the perception of seasonal variation in fruit abundance (Zhang and Wang, 1995). Further, there is a lag between the timing when a fruit is produced in the canopy and the moment it is dispersed (or dropped from the mother tree) that depends on the ripening time of the species (Zhang and Wang, 1995; Morellato et al., 2010). In addition, plants bearing very small seeds or fruits ( $<1 \mathrm{~mm}$ in diameter, the size of the mesh) are rarely sampled by traps, so there is a systematic size bias, although such tiny seeds are infrequent in forests so the method is adequate (Wright and Calderón, 1995). Finally, traps present a "chance concentration effect" in which some species with much clumped fruits may be overestimated by a chance effect, such as when the trap is placed just below a fruitbearing tree or palm (Stevenson et al., 1998). A stratified sampling design would avoid oversampling a tree or habitat type (see Zhang and Wang, 1995 as example), but this approach is rare. Instead, seed traps are normally set in regular grids (e.g. Nouragues: Mendoza et al. 
unpublished) or, for logistic reasons, along trails in the forest (e.g. BCI: Wright and Calderón, 2006). Despite these caveats, seed traps undoubtedly offer advantages for quantitatively sampling fruit production and quantify other ecological processes such as seed dispersal distances and frugivore activity (e.g. Mendoza et al., 2015; Stevenson et al., 1998).

Fruit ground surveys represent another indirect method of phenological observation and consist of counting fallen fruits along an established transect (e.g. Hawes and Peres, 2016; Zhang and Wang, 1995; Genini et al., 2009). This method, also useful for estimating fruit biomass, was rarely used in our review (1.8\% of datasets). Fruit ground surveys have advantages for frugivore studies by allowing censusing large area and avoiding the chance concentration effect (Barlow and Peres, 2006). However, it also presents some of the caveats of fruit traps regarding time intervals between fruit production and dispersal, and overestimation of fruiting seasonality due to frugivore activity. In addition, fruit removal on the ground is faster than in traps (due to seed predation and/or fruit putrefaction Zhang and Wang, 1995), so more frequent censuses are recommended for this technique.

The same problems arise for studies recording animal faeces on seed traps (only $3.2 \%$ of datasets), given that they present a bias towards dietary preferences of the animal species studied. In addition, the high concentration of seeds in scats increases seed predation risk. However, this technique is useful as complementary phenological information for studies addressing dispersal activity of frugivorous vertebrates, typically primates (e.g. González-Zamora et al., 2014).

The use of herbarium voucher specimens to extract fruiting patterns is still rare as a community-wide estimative across the Neotropics $(4.1 \%$ of datasets, Fig. 4). This less orthodox approach dates from the 1960s for the tropics (Croat, 1969) and several workers have noted its comparability with field studies (Borchert, 1996; Primack et al., 2004; Proença et al., 2012). Although it can be a powerful tool to detect phenological patterns of some species (Miller-Rushing et al., 2006; Zalamea et al., 2011), they are less frequently used at the community level (see Croat, 1975; or Ter Steege and Persaud, 1991 as exceptions). Herbarium collections are also typically combined with other sources of information, such as floristic surveys (e.g. Arbeláez and Parrado-Rosselli, 2005; Tannus et al., 2006), or literature reviews (e.g. Ter Steege and Persaud, 1991). In addition, herbarium vouchers register more frequently flowering than fruiting information (e.g. a survey of Brazilian herbaria shows that vouchers with flowering data are twice more frequent that those with fruiting data; G. Carvalho, personal communication), so they may be less useful to survey fruiting dates. However, as some collections date back to 1800 as in the case of Brazilian herbaria (G. Carvalho, personal communication), this is perhaps the only source of historical phenological information for the Neotropics. We therefore encourage future research expanding the use of herbarium-based data to analyze long phenological series in relation to climate change in the tropics.

All of these observation methods can involve several sampling techniques (Box 1): the most typical is to follow a pre-established linear transect or plot (d'Eça-Neves and Morellato, 2004), where phenological censuses are regularly conducted. However, some studies have a commercial or ecological interest for some tree species and therefore, workers systematically search for these species within a given area (e.g. Engel and Martins, 2005). Floristic surveys are normally conducted using the walking-and-collecting method, in which researchers follow trails and collect the species they find along their way (e.g. Frenedozo, 2004). Animal-focused studies can present phenological data as complementary information on diets, but in this case censuses are normally done on food-species (e.g. Santos et al., 2013).

\subsection{Plant habits and vegetation types sampled}

Some of the most species-rich ecoregions on Earth are in the Neotropics, which contains six of the 25 global biodiversity hotspots: i.e. Brazilian Atlantic forest, Cerrado, Tropical Andes, Caribbean,
Mesoamerica, and Chocó/Darién/Western Ecuador (Myers et al., 2000). The Amazon biome represents the largest continuous tract of tropical forest, and has the world's largest stock of aboveground terrestrial carbon and the most species-rich woody flora (Ter Steege et al., 2013). This extremely high diversity in vegetation types has been classified in different ways. Davis et al.'s (1997) broad classification includes as major terrestrial vegetation types: evergreen and semi-evergreen moist forests, tropical dry forests, open grassy savannas, desert and arid steppes, temperate evergreen forests, and montane formations (Table 1). This classification has been extended by Olson et al. (2001), who distinguished 867 ecoregions nested within 14 biomes. From these, 168 are represented in the Neotropics; the cerrado, the dry Chaco, the southwestern Amazon moist forests, and the caatinga being the most extensive in area (Olson et al., 2001). Other classifications of Neotropical biomes can be found in Arroyo et al. (2010), Metzger et al. (2013) and Jaramillo and Cárdenas (2013).

Given the description and site localities of each data source, we redefined the vegetation type of each study site following the consolidated version of the ecoregions of Olson et al. (2001), distinguishing a total of nine vegetation types: tropical evergreen forest (hereafter, rainforest), seasonal forest, tropical dry forest, cerrado woodland, desert and xeric shrubland, open grassy savanna, temperate evergreen forest, montane formation, and seasonally-flooded forest (see Table 1 for a more detailed description). We distinguished seasonally-flooded forests (wetlands, gallery forests, and Amazonian várzea and igapó forest) as a separate category regardless of the biome in which they were embedded, because fruiting phenology is primarily triggered by regional variation in flood pulses. Olson's classification was extracted from a freely available GIS layer (http://www.worldwildlife.org/publications/ terrestrial-ecoregions-of-the-world) and the attribution of vegetation types to our database sites was done using ESRI ${ }^{\circ}$ ArcMap $^{\mathrm{TM}}$ 10.x.

The uneven geographic distribution of phenological studies (Fig. 2) was also reflected in the skewed distribution among vegetation types (Fig. 5). The largest proportion of datasets were classified as rainforests (44.5\%), whereas temperate evergreen forests represented the least studied vegetation type (2.3\%), also due to their reduced land cover (Table 1 and Fig. 5). Although tropical dry forests account for a vast area (Quesada et al., 2009; Sánchez-Azofeifa et al., 2005), phenological studies were restricted to Costa Rica (Guanacaste and Comelco), Mexico (Chamela), eastern Ecuador, and Peru (12\% of datasets). Some important Neotropical dry forests such as the Chiquitano Bolivian dry forest were only represented by a single study (Justiniano and Fredericksen, 2000). Further, the large dry forests in South America (Brazil, Peru, Ecuador, Bolivia, Venezuela) and the Caribbean (e.g. Bahamas, Dominican Republic, Haiti, Jamaica) remained unstudied (at least until 2013).

Although tropical rainforests contain the largest number of phenological studies, large areas of the Amazon Basin (such as the Brazilian states of Acre, Rondonia and Mato Grosso) have been completely neglected. Some $8.3 \%$ of all datasets fall within the cerrado woodland (Table 1), but again little phenological information is available from vast areas of Central Brazil dominated by this vegetation.

Plant species richness varies greatly across Olson's ecoregions (Kier et al., 2005), and phenological species monitoring significantly varied across vegetation types of our review (linear model with the number of species varying as a function of vegetation types; $\mathrm{F}_{8,208}=2.9, p=$ 0.005 ; Fig. 6$)$. The largest number of species monitored were in the cerrado, open grassy savannas, rainforests, and seasonal forests (median range of number of species sampled $=76-90$; Fig. 6), whereas tropical dry forests and desert and arid shrublands had the least diverse samples ( median $=27-29$ species; Fig. 6). However, the richness of focal species sampled is likely related to the regional scale floristic diversity in each ecoregion. We therefore calculated a ratio $p$ of sampling effort as following: $p=s / S$, where $s$ is the number of species sampled in each phenological study, and $S$ is the estimated number of plant species within each ecoregion according to Kier et al. (2005). As expected, taxonomic 
Table 1

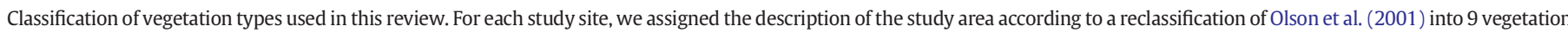

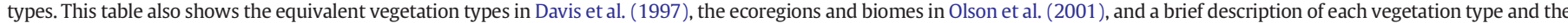
number of associated fruiting phenology datasets.

\begin{tabular}{|c|c|c|c|c|c|}
\hline $\begin{array}{l}\text { Vegetation } \\
\text { classification } \\
\text { of this } \\
\text { review }\end{array}$ & $\begin{array}{l}\text { Vegetation } \\
\text { classification of } \\
\text { Davis et al. } \\
\text { (1997) }\end{array}$ & Ecoregions of Olson et al. (2001) & Biomes of Olson et al. (2001) & Description of vegetation types & $\begin{array}{l}\text { Number } \\
\text { of } \\
\text { datasets }\end{array}$ \\
\hline Rainforest & $\begin{array}{l}\text { Tropical moist } \\
\text { forest }\end{array}$ & $\begin{array}{l}\text { Alto Paraná Atlantic forests; Bahia Coastal } \\
\text { forest; Caquetá moist forest; Central } \\
\text { American pine-oak forests; Guianan moist } \\
\text { forests; Guianan piedmont and lowland } \\
\text { moist forests; Iquitos várzea; Isthmian- } \\
\text { Atlantic moist forests; Isthmian-Pacific } \\
\text { moist forests; Juruá-Purus moist forests; } \\
\text { Madeira-Tapajós moist forests; Marajó } \\
\text { várzea; Maranhão Babaçu forests; Monte } \\
\text { Alegre varzeá; Napo moist forests; } \\
\text { Negro-Branco moist forests; Pernambuco } \\
\text { coastal forests; Pernambuco interior for- } \\
\text { ests; Petén-Veracruz moist forests; Puerto } \\
\text { Rican moist forests; Purus várzea; Serra do } \\
\text { Mar coastal forests; Sierra de los Tuxtlas; } \\
\text { Southern Atlantic mangroves; Southwest } \\
\text { Amazon moist forests; Talamancan mon- } \\
\text { tane forests; Tapajós-Xingu moist forests; } \\
\text { Trinidad and Tobago moist forests; } \\
\text { Uatuma-Trombetas moist forests; Xingu- } \\
\text { Tocantins-Araguaia moist forests }\end{array}$ & $\begin{array}{l}\text { Tropical and Subtropical Moist Broadleaf } \\
\text { Forests }\end{array}$ & $\begin{array}{l}\text { Lowland forests of the Amazon Basin; } \\
\text { Brazilian Atlantic forest, restinga forest; } \\
\text { lowland moist forests of Central America, } \\
\text { Caribe and Mexico; Chocó region of } \\
\text { Colombia and Ecuador }\end{array}$ & 97 \\
\hline $\begin{array}{l}\text { Seasonal } \\
\text { forest }\end{array}$ & $\begin{array}{l}\text { Tropical moist } \\
\text { forest }\end{array}$ & $\begin{array}{l}\text { Alto Paraná Atlantic forests; Alto Paraná } \\
\text { Atlantic forests; Isthmian-Atlantic moist } \\
\text { forests; Serra do Mar coastal forests }\end{array}$ & $\begin{array}{l}\text { Tropical and Subtropical Moist Broadleaf } \\
\text { Forests }\end{array}$ & $\begin{array}{l}\text { Central America seasonal forests; } \\
\text { semideciduous forests of Brazil }\end{array}$ & 13 \\
\hline $\begin{array}{l}\text { Tropical dry } \\
\text { forest }\end{array}$ & $\begin{array}{l}\text { Tropical dry } \\
\text { forest }\end{array}$ & $\begin{array}{l}\text { Alto Paraná Atlantic forests; Bahia coastal } \\
\text { forests; Balsas dry forests; Central } \\
\text { American dry forests; } \\
\text { Cerrado; Chiquitano dry forests; Eastern } \\
\text { Cordillera real montane forests; Jalisco dry } \\
\text { forests; Jamaican dry forests; Pantanal; } \\
\text { Pernambuco interior forests; Tumbes- } \\
\text { Piura dry forests; Western Ecuador moist } \\
\text { forests }\end{array}$ & $\begin{array}{l}\text { Tropical and Subtropical Moist Broadleaf } \\
\text { Forests }\end{array}$ & $\begin{array}{l}\text { Woody dry forests along the Pacific side of } \\
\text { Mexico and Central America, coastal } \\
\text { Ecuador and adjacent Peru, Chiquitania } \\
\text { area of eastern Bolivia, calcareous associ- } \\
\text { ated forests in Jamaica, Brazil and other } \\
\text { areas; interior forests of Pernambuco }\end{array}$ & 26 \\
\hline $\begin{array}{l}\text { Cerrado } \\
\text { woodland }\end{array}$ & $\begin{array}{l}\text { Tropical dry } \\
\text { forest }\end{array}$ & Cerrado; Madeira-Tapajós moist forests & $\begin{array}{l}\text { Tropical and subtropical grasslands, } \\
\text { savannas, and shrublands }\end{array}$ & $\begin{array}{l}\text { Cerrado sensu stricto and cerradão of } \\
\text { Brazil }\end{array}$ & 18 \\
\hline $\begin{array}{l}\text { Desert and } \\
\text { xeric } \\
\text { shrublands }\end{array}$ & $\begin{array}{l}\text { Tropical dry } \\
\text { forest and desert } \\
\text { and arid step }\end{array}$ & Caatinga; Llanos; Guianan Savanna & Deserts and Xeric Shrublands & $\begin{array}{l}\text { Caatinga of NE Brazil, Llanos of Venezuela, } \\
\text { Gran Sabana in the Guayana region }\end{array}$ & 11 \\
\hline $\begin{array}{l}\text { Open grassy } \\
\text { savanna }\end{array}$ & $\begin{array}{l}\text { Open grassy } \\
\text { savanna }\end{array}$ & $\begin{array}{l}\text { Cerrado; Chiquitano dry forests; Guianan } \\
\text { savanna; Llanos }\end{array}$ & $\begin{array}{l}\text { Tropical and subtropical grasslands, } \\
\text { savannas, and shrublands; Tropical and } \\
\text { Subtropical Dry Broadleaf Forests }\end{array}$ & $\begin{array}{l}\text { Cerrado grassland (campo sujo) and open } \\
\text { grassy savannas of the Llanos of Colombia } \\
\text { and Venezuela, grassy areas of Pantanal of } \\
\text { Brazil }\end{array}$ & 13 \\
\hline $\begin{array}{l}\text { Temperate } \\
\text { evergreen } \\
\text { forests }\end{array}$ & $\begin{array}{l}\text { Temperate } \\
\text { evergreen } \\
\text { forests }\end{array}$ & $\begin{array}{l}\text { Araucaria moist forests; Central American } \\
\text { pine-oak forests; Trans-Mexican Volcanic } \\
\text { Belt pine-oak forests }\end{array}$ & $\begin{array}{l}\text { Tropical and Subtropical Moist Broadleaf } \\
\text { Forests; } \\
\text { Tropical and Subtropical Coniferous } \\
\text { Forests }\end{array}$ & $\begin{array}{l}\text { Araucarian forests of Southern Brazil and } \\
\text { pine-oak forests of Southern Mexico and } \\
\text { Central America }\end{array}$ & 5 \\
\hline $\begin{array}{l}\text { Montane } \\
\text { formations }\end{array}$ & $\begin{array}{l}\text { Temperate } \\
\text { evergreen } \\
\text { forests }\end{array}$ & $\begin{array}{l}\text { Campos Rupestres montane savanna; } \\
\text { Cauca Valley montane forests; Central } \\
\text { Andean wet puna; Eastern Cordillera real } \\
\text { montane forests; Magdalena Valley } \\
\text { montane forests; Northwestern Andean } \\
\text { montane forests; Oaxacan montane } \\
\text { forests; Sierra Madre de Chiapas moist } \\
\text { forests; Talamancan montane forests; }\end{array}$ & $\begin{array}{l}\text { Montane Grasslands and Shrublands; } \\
\text { Tropical and subtropical grasslands, } \\
\text { savannas, and shrublands; } \\
\text { Tropical and Subtropical Moist Broadleaf } \\
\text { Forests }\end{array}$ & $\begin{array}{l}\text { Cloud forests of the Andes, Central } \\
\text { America, and South of Mexico; rupestrian } \\
\text { fields (campos rupestres) of Brazil }\end{array}$ & 11 \\
\hline $\begin{array}{l}\text { Seasonally } \\
\text { flooded } \\
\text { forests }\end{array}$ & $\begin{array}{l}\text { (Non-specifically } \\
\text { separated) }\end{array}$ & $\begin{array}{l}\text { Alto Paraná Atlantic forests; Araucaria } \\
\text { moist forests; Amazon-Orinoco-Southern } \\
\text { Caribbean mangroves; Araucaria moist } \\
\text { forests; Caatinga; Cerrado; } \\
\text { Japurá-Solimoes-Negro moist forests; } \\
\text { Juruá-Purus moist forests; Llanos; } \\
\text { Madeira-Tapajós moist forests; } \\
\text { Mesoamerican Gulf-Caribbean } \\
\text { mangroves; Monte Alegre várzea; } \\
\text { Pantanal; Purus várzea; Tocantins/Pindare } \\
\text { Moist Forest }\end{array}$ & $\begin{array}{l}\text { Deserts and Xeric Shrublands; Flooded } \\
\text { Grasslands and Savannas; Mangroves; } \\
\text { Tropical and subtropical grasslands, } \\
\text { savannas, and shrublands; Tropical and } \\
\text { Subtropical Moist Broadleaf Forests }\end{array}$ & $\begin{array}{l}\text { Seasonally flooded forests associated with } \\
\text { rivers and swamps, distributed in different } \\
\text { biomes; mangroves; várzea and igapó } \\
\text { forests of the Amazon Basin and Orinoco } \\
\text { River. }\end{array}$ & 24 \\
\hline
\end{tabular}

sampling effort in phenological studies $(p)$ was extremely low and represented only $\sim 2 \%$ of the regional flora (overall mean across vegetation types; Fig. 6). These low $p$ values are expected since the estimates of plant species richness were done at large spatial scale (ecoregions), whereas phenological studies were done at local scales, thereby reducing the proportion of species sampled if compared to the local flora. This incongruence of scale is also common in other ecological studies, but our estimate of sample effort $(p)$ allowed comparisons across vegetation 


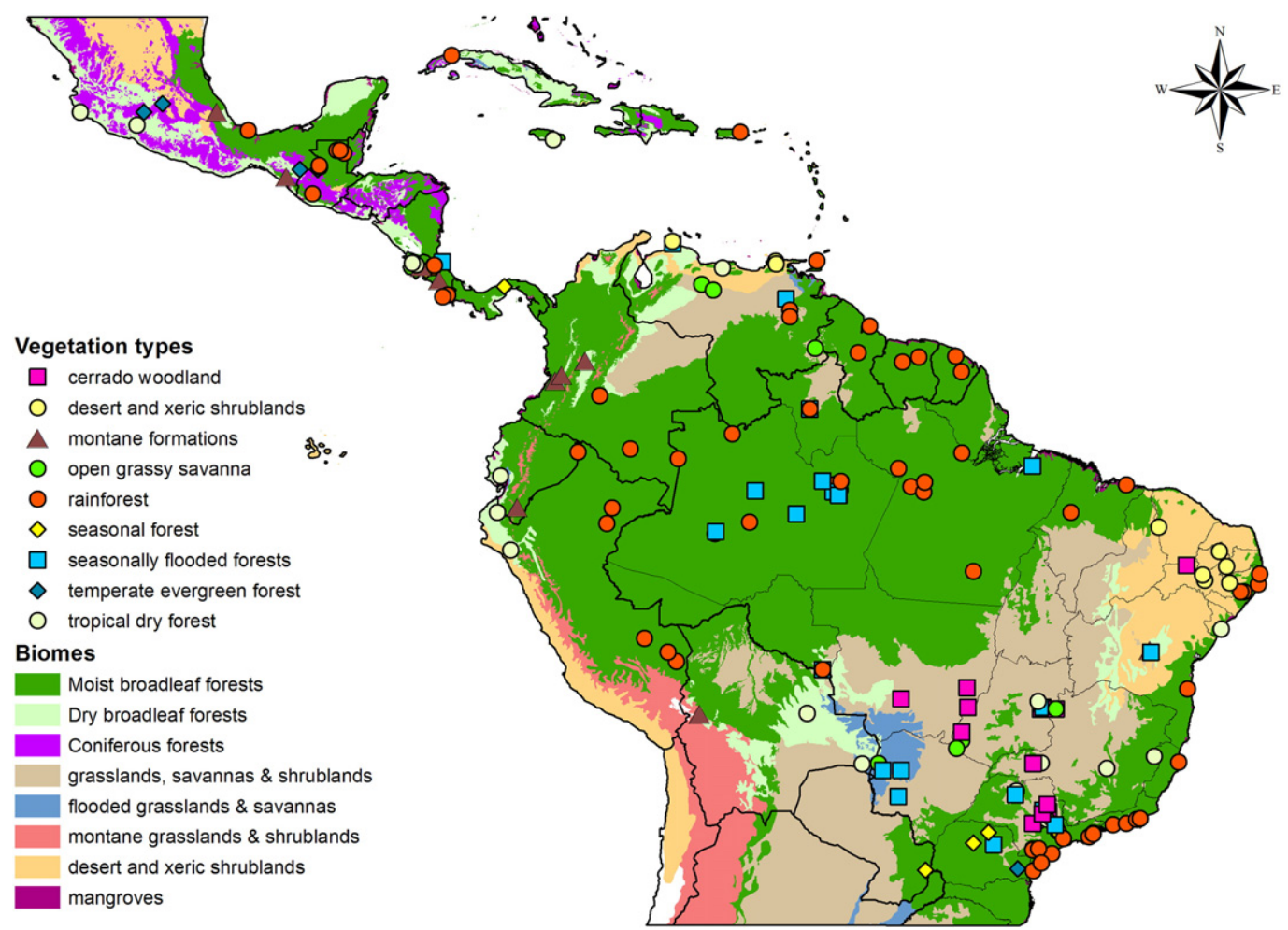

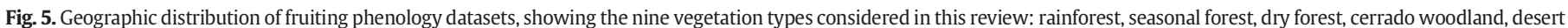

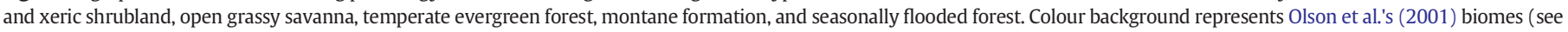
legend).

types. Sample taxonomic effort was highest in open grassy savannas and desert/xeric shrublands, despite their absolute small number of species sampled and sample sizes (Table 1 \& Fig. 6). The most diverse vegetation types such as the cerrado, tropical dry forest and rainforests exhibited the lowest sample efforts according to the $p$ ratio (Fig. 6). Despite their overall low values, seasonally dry forests showed a relatively high taxonomic sampling effort (Fig. 6).
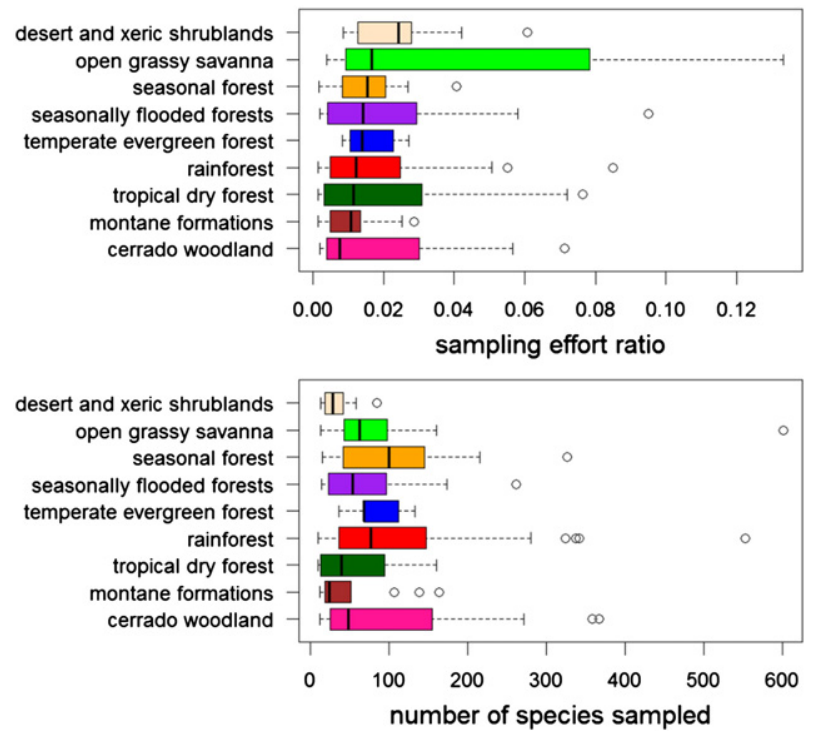

Fig. 6. Boxplots indicating the sampling effort $p$ (ratio between the number of species sampled per dataset and the estimated number of species across ecoregions; upper panel); and number of species sampled (lower panel) per vegetation type. Horizonta bars are coloured according to the legend of vegetation types in Fig. 5 and are ordered from the highest to the lowest median value or $p$. See Table 1 for the number of datasets in each vegetation type.
In relation to lifeforms, trees were the most frequently studied (81.0\%), followed by shrubs (37.7\%), woody lianas (20.3\%), and epiphytes (11.8\%). Because we explicitly excluded studies based entirely on herbaceous vegetation, the percentage of datasets including any herb species was relatively low (19.4\%), although this does not necessarily reflect the importance of this lifeform.

\section{Environmental drivers of fruiting phenology across the Neotropics}

Plant phenology responds to the relative forcing of abiotic vs. biotic factors (Memmott et al., 2007; Rathcke and Lacey, 1985; van Schaik et al., 1993). Biotic factors include intra- and inter-specific competition for resources, which affect plant interactions with pollinators, seed dispersers, seed predators and herbivores (Rathcke and Lacey, 1985; Ehrlén, 2015).

Staggered or clumped fruit production are then suggested to be strategies to avoid competition for effective dispersers, increase frugivore visitation rates, and escape pre- or post-dispersal seed predators (Fenner, 1998; Janzen, 1967; Janzen, 1971; Rathcke and Lacey, 1985; van Schaik et al., 1993). An extreme case of synchronized and massive fruit production is masting, which may be a strategy of plants to cope with seed predators and attract dispersers (Kelly and Sork, 2002; Mendoza et al., 2015). Despite the ultimate selective pressure exerted by biotic factors, climate is typically the proximate environmental cue that triggers plant reproduction and determines the timing of life cycles (van Schaik et al., 1993). In tropical ecosystems, biotic interactions are considered more influential in shaping fruit phenology compared to abiotic factors, under the deeply entrenched assumption that climatic variables are more constant than in temperate biomes (Morellato et al., 2000, 2013). However, $78.5 \%$ of the datasets compiled in our review explicitly addressed an abiotic variable in attempting to explain patterns of fruiting phenology (Table 2), whereas data in only 6\% of datasets were related to biotic factors. This dominance of climate and 
Table 2

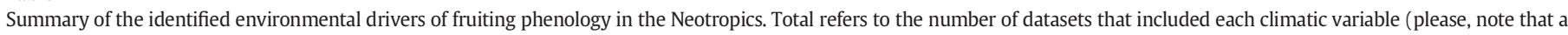

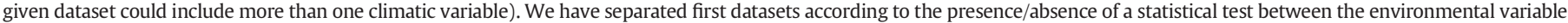

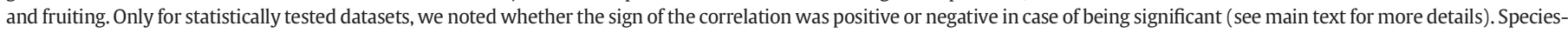
specific correlations refer that the sign was different depending on the analyzed species.

\begin{tabular}{|c|c|c|c|c|c|c|}
\hline \multirow[t]{2}{*}{ Climatic driver } & \multirow[t]{2}{*}{ Total } & \multirow[t]{2}{*}{ Statistically non-tested } & \multicolumn{4}{|c|}{ Statistically tested correlation with fruiting phenology } \\
\hline & & & Positive & Negative & Non-significant & Species-specific \\
\hline Rainfall & $160(73.4 \%)$ & 80 & 26 & 17 & 32 & 4 \\
\hline Air temperature & $42(19.3 \%)$ & 1 & 14 & 7 & 15 & 4 \\
\hline Day length & $20(9.17 \%)$ & & 4 & 6 & 10 & \\
\hline Flooding or tidal regime & $13(5.9 \%)$ & 5 & 5 & & 3 & \\
\hline Irradiance & $7(3.21 \%)$ & 1 & 6 & & & \\
\hline ENSO & $3(1.37 \%)$ & 1 & 1 & & 1 & \\
\hline Air humidity & $3(1.37 \%)$ & & 1 & & 2 & \\
\hline Evaporation & $1(0.45 \%)$ & & & 1 & & \\
\hline None analyzed (or original data) & $48(22.01 \%)$ & & & & & \\
\hline Total number of datasets & 218 & & & & & \\
\hline
\end{tabular}

other environmental factors as explanatory drivers of fruiting can be attributed to two explanations: (1) ultimate biotic drivers of fruiting are in general difficult to disentangle and require evolutionary approaches that are rarely undertaken (van Schaik et al., 1993); and (2) anthropogenic climate change has set strong research and funding priorities on impacts of climate on ecosystems (IPCC, 2014). Although abiotic factors were generally addressed, $55 \%$ of datasets did not include any statistical inference in examining phenological patterns. Rather, they qualitatively described the fruiting period in relation to some environmental gradient, typically rainfall seasonality (e.g. Frankie et al., 1974; Justiniano and Fredericksen, 2000; Mikich and Silva, 2001; Ragusa-Netto and Silva, 2007), but also other variables such as inundation regime (e.g. Kubitzki and Ziburski, 1994) or ENSO events (Wright et al., 1999). Considering studies that included any statistical test, the most common approach was simple correlative analysis using either Spearman or Pearson correlations (85.5\%, e.g. Morellato et al., 2000; Wallace and Painter, 2002). The second most used practice for analyzing phenological records was the use of simple or multiple linear regression (9.6\%, e.g. Engel and Martins, 2005), which also has a correlational basis. All these correlative techniques fail to account for the auto-correlated nature of phenological time series (Hudson and Keatley, 2010). Some statistical attempts to solve this have barely been used in the Neotropics (4.8\%), such as cross-correlations between environmental variables and phenology (Wright and Calderón, 2006) or power spectrum analysis (Bendix et al., 2006).

Of the climatic drivers, rainfall was the most commonly reported (73.4\% of datasets, Table 2) for all types of vegetation (Table S1). Especially in the case of desert and xeric shrubland, all datasets included this variable (Table S1). The typical pattern described in the literature is that phenology will markedly respond to strong rainfall seasonality (Borchert et al., 2005; Morellato et al., 2013; van Schaik et al., 1993).
Although we did not measure rainfall seasonality, we indirectly tested this hypothesis by comparing the frequency of studies that related fruiting peaks during the dry and rainy season (or the transitions between them) using a chi-square analysis (Table 3 ). As the number of studies was very unequal, we only had sufficiently large sample sizes for rainforest, cerrado woodland, and seasonally flooded forest. Both rainforests $\left(\chi^{2}=26.023\right.$; $\left.\mathrm{df}=3 ; p<0.001\right)$ and cerrado woodlands $\left(\chi^{2}=10.706 ; \mathrm{df}=2 ; p<0.005\right)$ significantly showed more peaks during the rainy season, and we could not find significant differences for seasonally-flooded forests (Table 3). This contradicted the seasonality hypothesis in the case of rainforests, where a dominance of aseasonal or year-round fruiting would be expected (e.g. seminal work of Snow, 1965). Further quantitative analyses are therefore required to examine how rainfall seasonality affects fruiting patterns in rainforests, which can exhibit very diverse rainfall patterns. In the case of cerrado woodlands, the dominance of fruiting peaks in the rainy season is concordant with our expectations, given that rainfall is strongly seasonal in these areas (Batalha and Martins, 2004; Camargo et al., 2013). Seasonallyflooded forests may be dominated by the floodwater regime rather than rainfall seasonality and are therefore not concomitant with either dry or wet seasons (e.g. Parolin, 2000; Schöngart et al., 2002). In any case, the prevalence of fruiting during the dry or wet season also depends on the prevalent seed dispersal mode. Species bearing dry, wind-dispersed fruits normally peak during the dry season (Morellato and Leitão-Filho, 1996; Griz and Machado, 2001). This has been suggested to be an adaptation to improve wind-dispersal, as deciduous species typically drop their leaves during periods of water scarcity, thereby reducing obstacles for samaras and other similar dry-fruit structures (Morellato and Leitão-Filho, 1996; Griz and Machado, 2001). Fleshy fruits are normally dominant during the rainy season, as the pulp requires high water content for ripening (Chen et al., 2016). Seed

Table 3

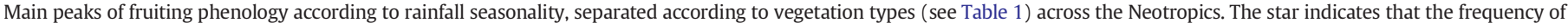

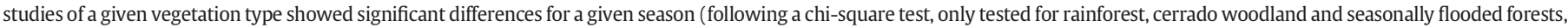
with transition seasons pooled). NA means not available.

\begin{tabular}{|c|c|c|c|c|c|c|c|}
\hline \multirow[t]{2}{*}{ Vegetation type } & \multicolumn{7}{|c|}{ Main peak of fruiting reported in the literature (number of datasets) } \\
\hline & Dry season & Rainy season & Transition dry to rainy season & Transition rainy to dry season & Aseasonal & NA & Total \\
\hline 1- Rainforest* & 17 & 42 & 7 & 4 & 16 & 2 & 97 \\
\hline 2- Seasonal forest & 6 & 3 & 2 & 0 & 1 & 0 & 13 \\
\hline 3- Tropical dry forest & 5 & 8 & 2 & 0 & 4 & 1 & 26 \\
\hline 4- Cerrado woodland* & 0 & 11 & 4 & 2 & 0 & 1 & 18 \\
\hline 5- Desert and xeric shrublands & 3 & 6 & 1 & 0 & 1 & 0 & 11 \\
\hline 6- Open grassy savanna & 4 & 2 & 2 & 1 & 2 & 0 & 13 \\
\hline 7- Temperate evergreen forest & 2 & 0 & 0 & 0 & 1 & 2 & 5 \\
\hline 8- Montane formations & 1 & 5 & 2 & 2 & 0 & 0 & 11 \\
\hline 9- Seasonally flooded forests & 5 & 10 & 2 & 3 & 0 & 4 & 24 \\
\hline
\end{tabular}


dispersal during either the dry or wet season requires different seed dormancy strategies to maximize optimal germination time, typically at the onset of the rainy season (Garwood, 1983).

Although temperature is a dominant phenological driver for temperate plants (e.g. Menzel et al., 2006; Schwartz and Reiter, 2000), it was only addressed by $19.3 \%$ of the datasets in our review (Table 2). This was the second most studied driver for all vegetation types (Table S1). In fact, there is a widespread belief that temperature does not constrain plant reproduction in low-latitude regions (e.g. Butt et al., 2015; Reich, 1995). However, some studies (e.g. Cortés-Flores et al., 2013; Staggemeier and Morellato, 2011) showed a significant correlation between temperature and fruiting. This includes not only elevated temperatures, but also cold shocks from subtropical frosts that affect flowering events, fruit maturation, and even the production of seeds that successfully germinate (e.g. Bendix et al., 2006).

Invariant cues such as photoperiod or daily insolation have been claimed to be more important for the timing and synchronicity of plant phenology, especially in areas with low climatic seasonality (i.e. close to the Equator, Borchert et al., 2005; Calle et al., 2010; Morellato et al., 2000). However, these cues are still rarely studied across the Neotropics ( $9.2 \%$ and $3.2 \%$ of datasets, respectively; Table 2 ), even though day-length is an easily acquired environmental variable that only requires the geo-coordinates of each study site. Datasets derived from rainforests presented a relatively higher rate of inclusion of photoperiod as climatic drivers (28\%; Table S1). This could be motivated by the low rainfall seasonality of some ever-wet rainforests, which may encourage workers to concentrate on other drivers. Solar irradiance values require more sophisticated meteorological stations, which can explain why this variable is so rarely analyzed (Table 2 and Table S1). Other environmental variables that were included comprise inundation or tidal regime in the case of flooded forests such as Amazonian várzea or igapó (33\%; Table S1), ENSO events (1\%) and air humidity (1\%; Table 2). Although understudied, inter-annual climatic events such ENSO might be critical to explain long-term phenological trends. For example, the analysis of an 18-year dataset from BCI (Panama), showed an increase in flower and seed production during positive ENSO events and a decrease during their negative phase (i.e. La Niña events) compared with neutral years (Wright and Calderón, 2006). Similar results were found for a 10-year dataset from Fushan rainforest (Taiwan), where both ENSO and frost events affected flower and seed production (Chang-Yang et al., 2016). Clearly, the paucity of research on inter-annual climatic events (ENSO and other teleconnections) effects also results from the lack of longterm fruiting phenology data series, as many monitoring years are required to undertake such time series analyses.

In short, although climate has been related to phenology in the vast majority of continental-scale studies, qualitative approaches are still very common in the tropical literature and several key environmental drivers remain poorly studied, especially for solar radiation or ENSO events. Much more research on multiple drivers is therefore needed, including novel approaches such as the influence of cloud cover (Pau et al., 2013), atmospheric $\mathrm{CO}_{2}$, soil humidity, soil nutrients, daily insolation (Borchert et al., 2015), and land-use change (Gordo and Sanz, 2010).

\section{Future climate changes and their impact on fruiting phenology}

Future climatic models predict drastic changes for most of the tropics; not only will mean temperatures increase (IPCC, 2013), but the frequency of increasingly stronger extreme events will rise. Temperature maxima, extreme droughts and flooding, mega ENSO events, and even exceptionally high tides are expected to be significantly more frequent in the future (Diffenbaugh and Scherer, 2011; IPCC, 2013; Kharin et al., 2013; Marengo et al., 2011). However, organismal and ecosystem responses to these extreme climatic events remain poorly understood (IPCC, 2014). First, there is large uncertainty in the effects of elevated $\mathrm{CO}_{2}$ in photosynthesis and transpiration of tropical forests, which have direct consequences to leaf, flower and fruit production (IPCC, 2014;
Malhi et al., 2009). Second, climatic models are equivocal in terms of changes in precipitation for tropical regions, varying according to geographic area and vegetation type (IPCC, 2014). The only consensus is that more severe and longer dry seasons will become more frequent, especially in the southeastern portions of the Amazon Basin (IPCC, 2014; Joetzjer et al., 2013). Phenological trends over long time series can give us some clues of plant responses to future climatic conditions. In addition, changes in fruit and seed production may have cascading community-wide consequences for myriad of vertebrate and invertebrate consumers (Butt et al., 2015; Morellato et al., 2016).

Our review uncovered the ten Neotropical sites for which long-term (>10 years) fruit phenology data are available (Fig. 2 ). As usual in ecological research in general and phenological studies in particular, longterm monitoring is shown once again to be very rare (Franklin, 1989; Lindenmayer and Likens, 2010; Morellato et al., 2013; Chambers et al., 2013). Nevertheless, these sites provide precious information to understand decadal trends in phenological dynamics, which has been already examined in temperate systems. Unfortunately, some sites such as Nouragues or Linhares have stopped monitoring activities, and efforts to resume observations would be very important. Parmesan's (2007) review showed a spring advancement of $2.3 \pm 0.3$ days per decade in a meta-analysis of 203 plant species, all of which from the Northern Hemisphere. A recent review also supported this generalized trend of spring advancement for the Southern Hemisphere, but only for temperate species and agricultural systems (Chambers et al., 2013). The different environmental filters that plants face from pollen dispersal to full seed maturation (Owens, 1995) may however obscure the impacts of climate on fruit production. In any case, determining the magnitude of directional trends in reproductive phenology and distinguishing them from typical cyclic oscillations is an urgent research need for tropical ecosystems.

\section{Concluding remarks}

Our exhaustive survey provides, for the first time, a quantitative overview of the state of the art of phenological research throughout the Neotropics, with a focus on fruiting. Although we did not review flowering phenology, $70.5 \%$ of the datasets compiled here addressed both flowers and fruits. Therefore, insights derived from our review on the geographic distribution of studies, sampling effort, monitoring techniques, and vegetation types may apply to Neotropical reproductive phenology in general.

Not surprisingly, we detected major gaps in terms of the geographic distribution of studies: large continental areas remain entirely unexplored, with most phenological studies concentrated in regions with a strong tradition of ecological research and funding support by either national or international institutions; i.e. State of São Paulo in Brazil, Panamá (BCI) and Costa Rica. In addition to this geographic bias, datasets compiled here generally resulted from short-term and low-diversity studies, often including only 2 to 5 years of sampling and fewer than 100 plant species. Neotropical vegetation was understudied in fruiting phenology datasets, and the ratio between numbers of species sampled and overall estimates of plant species richness was wholly insufficient for highly diverse vegetation types such as rainforests, seasonal forest and the cerrado, and only slightly more robust for less diverse vegetation types, such as desert and arid shrublands and open grassy savannas. In addition, the huge disparity of sampling techniques rendered any comparative analysis more difficult. Herbarium vouchers can provide precious information on reproduction timing that might overcame some temporal and spatial limitations of traditional phenological monitoring. In short, despite considerable advances in the attribution of phenology as an indicator of anthropogenic climate change, our review highlights that more collaborative effort towards standardized, longterm monitoring is required for the Neotropics.

Disentangling the cues that trigger plant phenology in general and fruiting cycles in particular is a long standing debate that is beyond 
the scope of this review. Other studies have discussed in detail the role of proximate and ultimate triggers of plant phenology and their evolutionary implications (Rathcke and Lacey, 1985; Reich, 1995; van Schaik et al., 1993). Our intention was instead to point out which drivers were used in phenological studies across the tropical Americas to explain fruiting patterns. We reveal that although climatic triggers have been mentioned in most fruiting datasets, this relationship was statistically tested in only $38 \%$ of cases. Since the beginning of phenological research, classic studies were essentially qualitative (Lieth, 1973; Schwartz, 2013). Although new studies attempt to incorporate a statistical approach between potential environmental drivers and plant responses, our review points out that more in-deep analyses are lacking even in recent studies (see Hudson and Keatley, 2010 for a review of statistical techniques in phenology). Phenological time series are intrinsically complex, which compounds difficulties in adjusting them to standard linear models. This complexity implies temporal autocorrelation, non-linearity, non-stationary properties (which means that time series can vary over time), and an excess of zeros due to the frequent non-occurrence of the phenophase of interest. Some of the possibilities for overcoming such problems include the use of Cumulative Sum Analysis (CUSUM) for detecting change-point in phenological data (Keatley and Hudson, 2012), Generalized Additive Models for Location, Scale and Shape (GAMLSS) (Hudson et al., 2010; Polansky and Boesch, 2013), cross-correlations (Wright and Calderón, 2006), and their extension by means of wavelet cross-correlations of bivariate time series (Hudson et al., 2011). Although these methods are rarely used in tropical studies, they ensure that drivers of phenology can be identified from multiple predictors and account for the non-linearity of time series and their complexity. Also, Bayesian techniques allow surmounting the pitfalls of linear regression (Dose and Menzel, 2004, Mendoza et al. unpublished) and can be especially helpful for detecting change points and rates of these changes in long-term series (Schleip et al., 2008). However, we warn that different statistical methods applied to phenology are typically not interchangeable and they can show differences in rates of change or even species responses (Keatley and Hudson, 2012).

We found that rainfall is predominantly identified as the main driver of fruiting cycles in the tropical literature, followed by ambient temperature. This corresponds well with the assumed paradigm for tropical vegetation in which rainfall seasonality is the principal driver of plant phenology (Morellato et al., 2013). In addition to this tradition of tropical research, temperature and rainfall data are normally the basic climatic variables that are available for most tropical sites, which explain their prevalence as abiotic cues. Lack of more sophisticated climatic variables may also explain why other environmental factors such as daylength, irradiance and ENSO events have been largely ignored, even though previous reviews had already highlighted the need to explore them in tropical phenology studies (Borchert et al., 2005; Calle et al., 2010; van Schaik et al., 1993).

Another widely held assumption in the literature predicts fruiting to be more affected by rainfall seasonality in more seasonal vegetation types. We found that studies conducted in rainforests and cerrado woodlands significantly showed a dominance of fruiting peaks during the rainy season. This contradicted general predictions for rainforests, because rainfall seasonality is expected to be low in this vegetation type. This can be explained because fleshy fruits require high levels of ground water for maturation, and they tend to dominate tropical woody plant communities towards the tropics (Chen et al., 2016).

\section{Future work}

Finally, given the quality and distribution of datasets uncovered here, we provide a shortlist of research priorities that we see as necessary to advance tropical plant phenology research.
1 - Prioritize research in understudied regions where adequate phenological monitoring is lacking, such as the Western and Southern Amazon, coastal Colombia, Central America (other than Costa Rica) or the Caribbean coast. In addition, sampling should be further extended to underrepresented vegetation types (e.g. tropical dry forests, desert and arid shrublands, tropical grasslands and montane formations). This phenological knowledge has relevant implications for conservation and management of native ecosystems (Morellato et al., 2016).

2 - Over and above the value of more fundamental and descriptive studies, we argue that more quantitative research linking plant phenology to consequences for biodiversity and climate change research is needed.

3 - In general, sampling effort was low for Neotropical fruiting studies in terms of monitoring length, number of species and number of stems or vouchers included, so we encourage researchers to expand their research, especially over longer time scales. However, we are aware of budget and staff limitations of such increased sampling effort.

4- The few existing long-term datasets are a very valuable source of information to support decadal analysis of climate-change effects on fruiting phenology. This could be complemented by data mining from herbarium specimens, which is rarely used in the tropics with outstanding possibilities to understand historical phenological changes.

5 - Although experimental studies may underestimate plant phenological responses to climate change (Wolkovich et al., 2012), they undoubtedly have value in understanding in detail the physiological mechanisms involved in plant life cycles. More ecophysiological approaches are therefore required to better understand tropical fruiting triggers. As example, the Amazon FACE experiment (Grossman, 2016) has a phenology monitoring program using time lapse cameras tracking leafing patterns.

6 - Despite the tradition of attributing tropical phenology to rainfall seasonality, our review has pointed out the need of putting more emphasis in underexplored drivers, namely irradiance seasonality and cold shocks. These barely explored climatic variables can provide important clues in the environmental control of fruiting events.

7- Quantitative analyses of fruiting peaks in relation to rainfall seasonality are necessary to confirm the current paradigm that fruiting is relatively continuous in aseasonal conditions, namely in the case of rainforests. In addition, this should take into account the community-wide dominance of fleshy fruits in these ecosystems.

8 - Population viability of frugivorous fauna depends heavily on the availability of fruit resources. Therefore, understanding how new climatic conditions (and particularly climate extremes) will affect fruiting phenology is helpful to detect areas where cascading consequences for fruit consumers could be mitigated (Butt et al., 2015) and improve biodiversity conservation (Morellato et al., 2016).

9 - There are a myriad of new statistical techniques which take into account the temporal autocorrelation inherent of phenological data, which have been barely used in phenological studies so far (Hudson and Keatley, 2010). In particular, wavelet analyses (Hudson et al., 2011), generalized additive models (Hudson et al., 2010; Polansky and Robbins, 2013), combined with Bayesian models (Schleip et al., 2010) are promising techniques for longterm datasets.

\section{Acknowledgements}

IM was funded by a São Paulo Research Foundation FAPESP fellowship (grant \#2012/21601-0) and a BEPE fellowship (grant \#2013/ 21968-3). IM was hosted by P. Jordano at the Doñana Biological Station during final writing of this manuscript. LPCM receives a research 
productivity fellowship from CNPq. Most datasets from the Atlantic Forest, Cerrado and Amazonia were compiled under the financial support of FAPESP (grants \#2007/59779-6, \#2006/61759-0 and \#2010/513070 and \#2013/50155-0) to LPCM. CAP was funded primarily by the Natural Environment Research Council (NERC) of the UK (NE/J01401X/1). We thank V. Arroyo-Rodríguez, A. Barnett, C. Donatti, G. Galdino, A. González-Zamora, COTERC, A. Vreedzaam, J. Hawes, A. Luna, C. Vath, D. J. Brightsmith, G. Martínez-Sovero, M. Ríos, C.E.T. Paine, V. Swamy, and R. Wallace for original data. L.F. Cancián provided GIS assistance, and M.G.G. Camargo and E. Gressler helped in bibliographic searches. J. Vázquez-Navarro and other researchers at the UNESP Phenology Lab provided useful comments. IM thanks J. Vázquez-Navarro for his aid in parental care of their newborn baby during the writing of this manuscript. We thank T.J. Horscroft for both inviting a submission to Global and Planetary Change after our participation in the symposium on Phenology of the EGU General Assembly 2014 and his subsequent assistance. The authors sincerely thank two anonymous reviewers for their suggestions in a previous version of this manuscript.

\section{Appendix A. Supplementary data}

Supplementary data associated with this article can be found in the online version, at http://dx.doi.org/10.1016/j.gloplacha.2016.12.001. These data include Google maps of the most important areas described in this article.

\section{References}

Alencar, J.C., Almeida, R.A., Fernandes, N.P., 1979. Fenologia de espécies florestais em floresta tropical úmida de terra firme na Amazônia Central. Acta Amazon. 1, 63-97.

Allen, P.H., 1956. The Rainforests of Golfo Dulce. Univ. Florida Press, Gainesville 417 pp.

Alvim, PT. 1964. Periodicidade do crescimento das árvores em climas tropicais. Congresso da Sociedade Botânica do Brasil. Anais do XV Congresso Nacional de Botânica, Porto Alegre, pp. 405-422 separata n. 1242

Antonelli, A., Sanmartin, I., 2011. Why are there so many plant species in the Neotropics? Taxon 60 (2), 403-414.

Arbeláez, M.V., Parrado-Rosselli, A., 2005. Seed dispersal modes of the sandstone plateau vegetation of the middle Caquetá river region, Colombian Amazonia. Biotropica 37 (1), 64-72.

Archibold, O.W., 1994. Ecology of World Vegetation. Chapman and Hall, London.

Arroyo, K.T., Dirzo, R., Castillas, J.C., Cejas, F., Joly, C.A., 2010. Biodiversity in Latin America and the Caribbean: An Assessment of Knowledge, Research Scope and Priority Areas, 1. CONACYT, Rio de Janeiro and Mexico City 332 pp.

Barlow, J., Peres, C.A., 2006. Effects of single and recurrent wildfires on fruit production and large vertebrate abundance in a central Amazonian forest. Biodivers. Conserv. 15 (3), 985-1012.

Batalha, M.A., Martins, F.R., 2004. Reproductive phenology of the cerrado plant community in Emas National Park (central Brazil). Aust. J. Bot. 52 (2), 149-161.

Bendix, J., et al., 2006. Seasonality of weather and tree phenology in a tropical evergreen mountain rain forest. Int. J. Biometeorol. 50 (6), 370-384.

Blake, J.G., Loiselle, B.A., Moermond, T.C., Levey, D.J., Denslow, J.S., 1990. Quantifying abundance of fruits for birds in tropical habitats. Stud. Avian Biol. 13, 73-79.

Borchert, R., 1996. Phenology and flowering periodicity of neotropical dry forest species: evidence from herbarium collections. J. Trop. Ecol. 12, 65-80.

Borchert, R., et al., 2005. Photoperiodic induction of synchronous flowering near the equator. Nature 433 (7026), 627-629.

Borchert, R., et al., 2015. Insolation and photoperiodic control of tree development near the equator. New Phytol. 205 (1), 7-13.

Both, C., Bouwhuis, S., Lessells, C.M., Visser, M.E., 2006. Climate change and population declines in a long-distance migratory bird. Nature 441 (7089), 81-83.

Boubli, J.P., 1997. Ecology of the Black Uakari Monkey, Cacajao melanocephaus melanocephalus. Pico da Neblina National Park, Brazil. University of California, Berkeley (PhD Thesis), $218 \mathrm{pp}$

Butt, N., et al., 2015. Cascading effects of climate extremes on vertebrate fauna through changes to low-latitude tree flowering and fruiting phenology. Glob. Chang. Biol. 21 (9), 3267-3277.

Calle, Z, et al., 2010. Seasonal variation in daily insolation induces synchronous bud break and flowering in the tropics. Trees 24 (5), 865-877.

Camargo, M.G.G., Cazetta, E., Schaefer, H.M., Morellato, L.P.C., 2013. Fruit color and contrast in seasonal habitats - a case study from a cerrado savanna. Oikos 122 (9), $1335-1342$

Catanzaro, M., Miranda, G., Palmer, L., Bajak, A., 2014. South American science: big players. Nature 510 (7504), 204-206

Chambers, L.E., et al., 2013. Changes in southern hemisphere phenology. PLoS Biol. 8 (10), e75514.
Chang-Yang, C.-H., Sun, I.F., Tsai, C.-H., Lu, C.-L., Hsieh, C.-F., 2016. ENSO and frost codetermine decade-long temporal variation in flower and seed production in a subtropical rain forest. J. Ecol. 104 (1), 44-54

Chapman, C.A., Wrangham, R., Chapman, L.J., 1994. Indexes of habitat-wide fruit abundance in tropical forests. Biotropica 26 (2), 160-171.

Chapman, C.A., et al., 1992. Estimators of fruit abundance of tropical trees. Biotropica 24 (4), 527-531.

Chen, S.-C., Cornwell, W.K., Zhang, H.-X., Moles, A.T., 2016. Plants show more flesh in the tropics: variation in fruit type along latitudinal and climatic gradients. Ecography.

Cleland, E.E., Chuine, I., Menzel, A., Mooney, H.A., Schwartz, M.D., 2007. Shifting plant phenology in response to global change. Trends Ecol. Evol. 22 (7), 357-365.

Cook, B.I., Wolkovich, E.M., Parmesan, C., 2012. Divergent responses to spring and winter warming drive community level flowering trends. Proc. Natl. Acad. Sci. U. S. A. 109 (23), 9000-9005

Cortés-Flores, J., Andresen, E., Cornejo-Tenorio, G., Ibarra-Manriquez, G., 2013. Fruiting phenology of seed dispersal syndromes in a Mexican neotropical temperate forest. For. Ecol. Manag. 289, 445-454.

Croat, T.B., 1969. Seasonal flowering behavior in Central Panama. Ann. Mo. Bot. Gard. 56 (3), 295-307.

Croat, T.B., 1975. Phenological behavior of habit and habitat classes on Barro Colorado Island (Panama Canal Zone). Biotropica 7 (4), 270-277.

Davis, T.A.W., Richards, P.W., 1933. The vegetation of Moraballi creek, British Guiana: an ecological study of a limited area of tropical forest. Parts I. J. Ecol. 21, 350-384

Davis, S.D., Heywood, V.H., Herrera-MacBride, O., Villa-Lobos, J., Hamilton, A.C., 1997. Centres of Plant Diversity: A Guide and Strategy for Their Conservation. The Americas. IUCN Publications Unit, Cambridge.

d'Eça-Neves, F.F., Morellato, L.P.C., 2004. Métodos de amostragem e avaliação utilizados em estudos fenológicos de florestas tropicais. Acta Bot. Bras. 18, 99-108.

Demarée, G.R., Rutishauser, T., 2009. Origins of the word "phenology". EOS Trans. Am. Geophys. Union 90 (34), 291.

Demarée, G.R., Rutishauser, T., 2011. From "periodical observations" to "anthochronology" and "phenology" - the scientific debate between Adolphe Quetelet and Charles Morren on the origin of the word "phenology". Int. J. Biometeorol. 55 (6), 753-761.

Develey, P.F., Peres, C.A., 2000. Resource seasonality and the structure of mixed species bird flocks in a coastal Atlantic forest of southeastern Brazil. J. Trop. Ecol. 16, 33-53.

Diffenbaugh, N.S., Scherer, M., 2011. Observational and model evidence of global emergence of permanent, unprecedented heat in the 20th and 21st centuries. Clim. Chang. 107 (3), 615-624.

Dose, V., Menzel, A., 2004. Bayesian analysis of climate change impacts in phenology. Glob. Chang. Biol. 10 (2), 259-272.

Ehrlén, J., 2015. Selection on flowering time in a life-cycle context. Oikos 124 (1), 92-101.

Engel, V.L., Martins, F.R., 2005. Reproductive phenology of Atlantic forest tree species in Brazil: an eleven year study. Trop. Ecol. 46 (1), 1-16.

Estrada, A., Coates Estrada, R., 2001. Species composition and reproductive phenology of bats in a tropical landscape at Los Tuxtlas, Mexico. J. Trop. Ecol. 17, 627-646.

Fenner, M., 1998. The phenology of growth and reproduction in plants. Perspect. Plant Ecol., Evol. Syst. 1 (1), 78-91

Forrest, J.R.K., 2016. Complex responses of insect phenology to climate change. Curr. Opin. Insect Sci. 17, 49-54.

Fournier, L.A., 1974. Un método cuantitativo para la medición de características fenológicas en árboles. Turrialba 24, 422.

Frankie, G.W., Baker, H.G., Opler, P.A., 1974. Comparative phenological studies of trees in tropical wet and dry forests in the lowlands of Costa Rica. J. Ecol. 62 (3), 881-919.

Franklin, J.F., 1989. Importance and Justification of Long-Term Studies in Ecology. In: Likens, G.E. (Ed.), Long-Term Studies in Ecology: Approaches and Alternatives. Springer New York, New York, NY, pp. 3-19.

Fraser, L.H., Keddy, P.A. (Eds.), 2005. The World's Largest Wetlands: Ecology and Conservation. Cambridge University Press, Cambridge $424 \mathrm{pp}$.

Frenedozo, R.D.C., 2004. Plant reproductive phenology and dispersal patterns after natural regeneration in a limestone mining spoil banks. Braz. Arch. Biol. Technol. 47 (2), 261-271.

Gallinat, A.S., Primack, R.B., Wagner, D.L., 2015. Autumn, the neglected season in climate change research. Trends Ecol. Evol. 30 (3), 169-176.

Garwood, N.C., 1983. Seed germination in a seasonal tropical forest in Panama: a community study. Ecology 53, 159-181.

Gautier, L., Spichiger, R., 1986. Ritmos de reproducción en el estrato arbóreo del Arborétum Jenaro Herrera (provincia de Requena, departamento de Loreto, Perú). Contribución al estudio de la flora y de la vegetación de la Amazonia peruana. X. Candollea 41, 193-207.

Genini, J., Galetti, M., Morellato, L.P.C., 2009. Fruiting phenology of palms and trees in an Atlantic rainforest land-bridge island. Flora 204 (2), 131-145.

Gill, A.L., et al., 2015. Changes in autumn senescence in northern hemisphere deciduous trees: a meta-analysis of autumn phenology studies. Ann. Bot. 116 (6), $875-888$

González-Zamora, A. et al., 2014. Contagious deposition of seeds in spider monkeys' sleeping trees limits effective seed dispersal in fragmented landscapes. PLoS One, 9(2), e89346.

Gordo, O., Sanz, J.J., 2010. Impact of climate change on plant phenology in Mediterranean ecosystems. Glob. Chang. Biol. 16 (3), 1082-1106.

Griz, L.M.S., Machado, I.C.S., 2001. Fruiting phenology and seed dispersal syndromes in caatinga, a tropical dry forest in the northeast of Brazil. J. Trop. Ecol. 17, 303-321.

Grossman, D., 2016. Amazon rainforest to get a growth check. Science 352 (6286), 635-636. 
Gupta, B.M., Sharma, P., Karisiddappa, C.R., 1997. Growth of research literature in scientific specialities. A modelling perspective. Scientometrics 40 (3), 507-528.

Hanya, G., Tsuji, Y., Grueter, C.C., 2013. Fruiting and flushing phenology in Asian tropical and temperate forests: implications for primate ecology. Primates 54 (2), 101-110.

Hawes, J.E., Peres, C.A., 2016. Patterns of plant phenology in Amazonian seasonally flooded and unflooded forests. Biotropica 465-475.

Hemingway, C.A., Overdorff, D.J., 1999. Sampling effects on food availability estimates: phenological method, sample size, and species composition. Biotropica 31 (2), 354-364.

Hudson, I.L., Keatley, M.R., 2010. Phenological Research: Methods for Environmental and Climate Change Analysis. Springer Netherlands, Dordrecht.

Hudson, I.L., Keatley, M.R., Kang, I., 2011. Wavelet characterization of eucalypt flowering and the influence of climate. Environ. Ecol. Stat. 18 (3), 513-533.

Hudson, I.L., Kim, S.W., Keatley, M.R., 2010. Climatic influences on the flowering phenology of four eucalypts: a GAMLSS approach. In: Hudson, L.I., Keatley, R.M. (Eds.), Phenological Research: Methods for Environmental and Climate Change Analysis. Springer Netherlands, Dordrecht, pp. 209-228.

Ibáñez, I., et al., 2010. Forecasting phenology under global warming. Philos. Trans. R. Soc., B 365 (1555), 3247-3260.

IPCC, 2013. Climate Change, 2013: The Physical Science Basis, Contribution of Working Group I to the Fifth Assessment Report of the IPCC. Cambridge University Press, Cambridge, United Kingdom and New York, NY, USA (1535 pp.)

IPCC, 2014. Climate Change 2014: Impacts, Adaptation, and Vulnerability. Part A: Global and Sectoral Aspects. Contribution of Working Group II to the Fifth Assessment Report of the Intergovernmental Panel on Climate Change (eds.). Cambridge University Press, Cambridge, United Kingdom and New York, NY, USA.

Janzen, D.H., 1967. Synchronization of sexual reproduction of trees within dry season in Central America. Evolution 21 (3), 620-637.

Janzen, D.H., 1971. Seed predation by animals. Annu. Rev. Ecol. Syst. 2, 465-492.

Jaramillo, C., Cárdenas, A., 2013. Global warming and neotropical rainforests: a historical perspective. Annu. Rev. Earth Planet. Sci. 41 (41), 741-766.

Joetzjer, E., Douville, H., Delire, C., Ciais, P., 2013. Present-day and future Amazonian precipitation in global climate models: CMIP5 versus CMIP3. Clim. Dyn. 41 (11), 2921-2936.

Justiniano, M.J., Fredericksen, T.S., 2000. Phenology of tree species in Bolivian dry forests. Biotropica 32 (2), 276-281.

Keatley, M.R., Hudson, I.L., 2010. Introduction and overview. In: Hudson, I.L., Keatley, M.R. (Eds.), Phenological Research: Methods for Environmental and Climate Change Analysis. Springer, Dordrecht, pp. 1-22.

Keatley, M.R., Hudson, I.L., 2012. Detecting change in an Australian flowering record: comparisons of linear regression and cumulative sum analysis change point analysis. Austral Ecology 37 (7), 825-835.

Kelly, D., Sork, V.L., 2002. Mast seeding in perennial plants: why, how, where? Annu. Rev. Ecol. Syst. 33, 427-447.

Kharin, V.V., Zwiers, F.W., Zhang, X., Wehner, M., 2013. Changes in temperature and precipitation extremes in the CMIP5 ensemble. Clim. Chang. 119 (2), 345-357.

Kier, G., et al., 2005. Global patterns of plant diversity and floristic knowledge. J. Biogeogr. 32 (7), 1107-1116.

Knowles, O.H., Parrotta, J.A., 1997. Phenological observations and tree seed characteristics in an equatorial moist forest at trombetas, Para State, Brazil. In: Lieth, H., Schwartz, M.D. (Eds.), Phenology in Seasonal Climates. Backhuys Publishers, Leiden, The Netherlands, pp. 67-84

Kubitzki, K., Ziburski, A., 1994. Seed dispersal in flood-plain forests of Amazonia. Biotropica 26 (1), 30-43.

Lieth, H., 1973. Phenology in Productivity Studies, Analysis of Temperate Forest Ecosystems. Springer, pp. 29-46.

Lindenmayer, D.B., Likens, G.E., 2010. The science and application of ecological monitoring. Biol. Conserv. 143 (6), 1317-1328.

Lobo, J., Aguilar, R., Chacón, E., Fuchs, E., 2008. Phenology of tree species of the Osa Peninsula and Golfo Dulce region, Costa Rica. In: Weissenhofer, A., et al. (Eds.), Natural and Cultural History of the Golfo Dulce Region, Costa Rica, pp. 547-556.

Malhi, Y., et al., 2009. Exploring the likelihood and mechanism of a climate-changeinduced dieback of the Amazon rainforest. Proc. Natl. Acad. Sci. U. S. A. 106 (49), 20610-20615.

Marengo, J.A., Tomasella, J., Soares, W.R., Alves, L.M., Nobre, C.A., 2011. Extreme climatic events in the Amazon basin. Theor. Appl. Climatol. 107 (1), 73-85.

Memmott, J., Craze, P.G., Waser, N.M., Price, M.V., 2007. Global warming and the disruption of plant-pollinator interactions. Ecol. Lett. 10 (8), 710-717.

Mendoza, I., et al., 2015. Does masting result in frugivore satiation? A test with Manilkara trees in French Guiana. J. Trop. Ecol. 2015 (31), 553-556.

Menzel, A., et al., 2006. European phenological response to climate change matches the warming pattern. Glob. Chang. Biol. 12 (10), 1969-1976.

Metzger, M.J., et al., 2013. A high-resolution bioclimate map of the world: a unifying framework for global biodiversity research and monitoring. Glob. Ecol. Biogeogr. 22 (5), 630-638.

Mikich, S.B., Silva, S.M., 2001. Floristic and phenological study of zoochoric species of Semideciduous Seasonal Forest remnants in the mid-west region of Parana State, Brazil. Acta Bot. Bras. 15 (1), 89-113.

Miller-Rushing, A.J., Primack, R.B., Primack, D., Mukunda, S., 2006. Photographs and herbarium specimens as tools to document phenological changes in response to global warming. Am. J. Bot. 93 (11), 1667-1674.

Morellato, L.P.C., Leitão-Filho, H., 1996. Reproductive phenology of climbers in a Southeastern Brazilian forest. Biotropica 28 (2), 180-191.

Morellato, L.P.C., Camargo, M.G.G., Gressler, E., 2013. South and Central America: Phenology overview and perspectives. In: Schwartz, M.D. (Ed.), Phenology: An Integrative Environmental Science. Kluwer Academic Publishers, The Netherlands, pp. 91-113.
Morellato, L.P.C., et al., 2000. Phenology of Atlantic rain forest trees: a comparative study. Biotropica 32 (4B), 811-823.

Morellato, L.P.C., et al., 2010. The influence of sampling method, sample size, and frequency of observations on plant phenological patterns and interpretation in tropical forest trees. Phenological Research: Methods for Environmental and Climate Change Analysis 99-121 pp.

Morellato, L.P.C., et al., 2016. Linking plant phenology to conservation biology. Biol. Conserv. 195, 60-72.

Morren, C., 1849. Le Globe, le Temps et la Vie. Bulletins de l'Académie royale des Sciences. des Lettres et des Beaux-Arts de Belgique XVI (2), 660-684

Myers, N., Mittermeier, R.A., Mittermeier, C.G., da Fonseca, G.A.B., Kent, J., 2000. Biodiversity hotspots for conservation priorities. Nature 403 (6772), 853-858.

Newstrom, L.E., Frankie, G.W., Baker, H.G., 1994. A new classification for plant phenology based on flowering patterns in lowland tropical rain-forest trees at La Selva, Costa Rica. Biotropica 26 (2), 141-159.

Olson, D.M., et al., 2001. Terrestrial ecoregions of the world: a new map of life on earth a new global map of terrestrial ecoregions provides an innovative tool for conserving biodiversity. Bioscience 51 (11), 933-938.

Opler, P.A., Frankie, G.W., Baker, H.G., 1980. Comparative phenological studies of treelet and shrub species in tropical wet and dry forests in the lowlands of Costa Rica. J. Ecol. 68 (1), 167-188.

Owens, J.N., 1995. Constraints to seed production: temperate and tropical forest trees. Tree Physiol. 15 (7-8), 477-484.

Palminteri, S., Powell, G.V., Peres, C.A., 2012. Advantages of granivory in seasonal environments: feeding ecology of an arboreal seed predator in Amazonian forests. Oikos 121 (11), 1896-1904.

Parmesan, C., 2006. Ecological and evolutionary responses to recent climate change, annual review of ecology evolution and systematics. Annu. Rev. Ecol. Evol. Syst. 637-669.

Parmesan, C., 2007. Influences of species, latitudes and methodologies on estimates of phenological response to global warming. Glob. Chang. Biol. 13 (9), 1860-1872.

Parmesan, C., Hanley, M.E., 2015. Plants and climate change: complexities and surprises. Ann. Bot. 116 (6), 849-864.

Parmesan, C., Yohe, G., 2003. A globally coherent fingerprint of climate change impacts across natural systems. Nature 421 (6918), 37-42.

Parolin, P., 2000. Phenology and $\mathrm{CO}_{2}$-assimilation of trees in central Amazonian floodplains. J. Trop. Ecol. 16, 465-473.

Pau, S., et al., 2013. Clouds and temperature drive dynamic changes in tropical flower production. Nat. Clim. Chang. 3 (9), 838-842.

Peres, C.A., 1994. Primate responses to phenological changes in an Amazonian terra-firme forest. Biotropica 26 (1), 98-112.

Persson, V., 2005. Effects of climatic seasonality on reproductive phenology of tropical forest plants. (PhD Thesis). University of Aberdeen, Aberdeen.

Polansky, L., Boesch, C., 2013. Long-term changes in fruit phenology in a west African lowland tropical rain forest are not explained by rainfall. Biotropica 45 (4), 434-440.

Polansky, L., Robbins, M.M., 2013. Generalized additive mixed models for disentangling long-term trends, local anomalies, and seasonality in fruit tree phenology. Ecol. Evol. 3 (9), 3141-3151.

Primack, D., Imbres, C., Primack, R.B., Miller-Rushing, A.J., Del Tredici, P., 2004. Herbarium specimens demonstrate earlier flowering times in response to warming in Boston. Am. J. Bot. 91 (8), 1260-1264.

Primack, R.B., et al., 2009. Spatial and interspecific variability in phenological responses to warming temperatures. Biol. Conserv. 142 (11), 2569-2577.

Proença, C.E.B., Filer, D.L., Lenza, E., Silva, J.S., Harris, S.A., 2012. Phenological predictability index in BRAHMS: a tool for herbarium-based phenological studies. Ecography 35 (4), 289-293.

Quesada, M., et al., 2009. Succession and management of tropical dry forests in the Americas: review and new perspectives. For. Ecol. Manag. 258 (6), 1014-1024.

Ragusa-Netto, J., Silva, R.R., 2007. Canopy phenology of a dry forest in western Brazil. Braz. J. Biol. 67 (3), 569-575.

Rathcke, B., Lacey, E.P., 1985. Phenological patterns of terrestrial plants. Annu. Rev. Ecol. Syst. 16, 179-214.

Regalado, A., 2010. Brazilian science: riding a gusher. Science 330 (6009), 1306-1312.

Reich, P.B., 1995. Phenology of tropical forests - patterns, causes, and consequences. Canadian Journal of Botany-Revue Canadienne De Botanique 73 (2), 164-174.

Reys, P., Galetti, M., Morellato, L.P.C., Sabino, J., 2005. Fenologia reprodutiva e disponibilidade de frutos de espécies arbóreas em mata ciliar no rio formoso, Mato Grosso do Sul. Biota Neotropica 5 (2).

Richardson, A.D., et al., 2013. Climate change, phenology, and phenological control of veg etation feedbacks to the climate system. Agric. For. Meteorol. 169, 156-173.

Root, T.L., et al., 2003. Fingerprints of global warming on wild animals and plants. Nature 421 (6918), 57-60.

Rosenzweig, C., et al., 2008. Attributing physical and biological impacts to anthropogenic climate change. Nature 453 (7193), 353-U20.

Sabatier, D., 1985. Saisonnalité et déterminisme du pic de fructification en fôret guyanaise. Revue d'Écologie (Terre et Vie) 40, 289-320.

Sakai, S., 2001. Phenological diversity in tropical forests. Popul. Ecol. 43 (1), 77-86.

Sánchez-Azofeifa, G.A., et al., 2005. Research priorities for neotropical dry forests 1. Biotropica 37 (4), 477-485

Santos, G.A.S.D., Bianchini, E., dos Reis, N.R., 2013. Seasonal variation of consumption of the species used as fruit source by brown howler monkeys (Alouatta clamitans) in southern Brazil. Biol. Neonate 13 (3), 148-153.

Schleip, C., Luterbacher, J., Menzel, A., 2008. Time series modeling and central European temperature impact assessment of phenological records over the last 250 years. J. Geophys. Res. Biogeosci. 113 (G4). 
Schleip, C., Menzel, A., Dose, V., 2010. Bayesian methods in phenology, Phenological Research: Methods for Environmental and Climate Change Analysis. Springer Netherlands, Dordrecht, pp. 229-254.

Schöngart, J., Piedade, M.T.F., Ludwigshausen, S., Horna, V., Worbes, M., 2002. Phenology and stem-growth periodicity of tree species in Amazonian floodplain forests. J. Trop. Ecol. 18, 581-597.

Schwartz, M.D., 2013. Introduction. In: Schwartz, M.D. (Ed.), Phenology: An Integrative Environmental Science. Springer, Netherlands, pp. 1-5.

Schwartz, M.D., Reiter, B.E., 2000. Changes in north American spring. Int. J. Climatol. 20 (8), 929-932.

Schwartz, M.D., Ahas, R., Aasa, A., 2006. Onset of spring starting earlier across the northern hemisphere. Glob. Chang. Biol. 12 (2), 343-351.

Snow, D.W., 1965. A possible selective factor in evolution of fruiting seasons in tropical forest. Oikos 15 (2), 274-281.

Sparks, T.H., Menzel, A., 2002. Observed changes in seasons: an overview. Int. J. Climatol. 22 (14), 1715-1725.

Staggemeier, V.G., Morellato, L.P.C., 2011. Reproductive phenology of coastal plain Atlantic forest vegetation: comparisons from seashore to foothills. Int. J. Biometeorol. 55 (6), 843-854.

Stevenson, P.R., Quiñones, M.J., Ahumada, J.A., 1998. Annual variation in fruiting pattern using two different methods in a lowland tropical forest, Tinigua National Park, Colombia. Biotropica 30 (1), 129-134.

Tannus, J.L.S., Assis, M.A., Morellato, L.P.C., 2006. Reproductive phenology in dry and wet grassland in an area of cerrado at southeastern Brazil, Itirapina - SP. Biota Neotropica 6 (3).

Ter Steege, H., Persaud, C.A., 1991. The phenology of a Guyanese timber species - a compilation of a century of observations. Vegetatio 95 (2), 177-198.

Ter Steege, H., et al., 2013. Hyperdominance in the Amazonian tree flora. Science 342 (6156)

Terborgh, J., 1983. The study site: its climate and vegetation. In: Terborgh, J.W. (Ed.), Monographs in Behavior and Ecology. Five New World Primates. A Study in Comparative Ecology. Princeton University press, New Jersey, pp. 8-24.
Ting, S., Hartley, S., Burns, K.C., 2008. Global patterns in fruiting seasons. Glob. Ecol. Biogeogr. 17 (5), 648-657.

van Schaik, C.P., Terborgh, J.W., Wright, S.J., 1993. The phenology of tropical forests: adaptive significance and consequences for primary consumers. Annu. Rev. Ecol. Syst. 24 (1), 353-377.

Vinkler, P., 2010. The Evaluation of Research by Scientometric Indicators. Elsevier.

Wallace, R.B., Painter, R.L.E., 2002. Phenological patterns in a southern Amazonian tropical forest: implications for sustainable management For. Ecol. Manag 160 (1-3), 19-33.

Wheelwright, N.T., 1986. A seven-year study of individual variation in fruit production in tropical bird-dispersed tree species in the family Lauraceae. In: Estrada, A., Fleming, T.H. (Eds.), Frugivores and Seed Dispersal. Dr. W. Junk Publishers, Dordrecht, The Netherlands, pp. 19-35.

Wolkovich, E.M., et al., 2012. Warming experiments underpredict plant phenological responses to climate change. Nature 485 (7399), 494-497.

Wright, S.J., Calderón, O., 1995. Phylogenetic patterns among tropical flowering phenologies. J. Ecol. 83 (6), 937-948.

Wright, S.J., Calderón, O., 2006. Seasonal, El Niño and longer term changes in flower and seed production in a moist tropical forest. Ecol. Lett. 9 (1), 35-44.

Wright, S.J., Carrasco, C., Calderón, O., Paton, S., 1999. The El Niño southern oscillation variable fruit production, and famine in a tropical forest. Ecology 80 (5), 1632-1647.

$\mathrm{Xu}$, L., et al., 2013. Temperature and vegetation seasonality diminishment over northern lands. Nat. Clim. Chang. 3 (6), 581-586.

Zalamea, P.C., et al., 2011. Continental-scale patterns of Cecropia reproductive phenology: evidence from herbarium specimens. Proc. R. Soc. B Biol. Sci. 278 (1717), 2437-2445.

Zhang, S.-Y., Wang, L.-X., 1995. Comparison of three fruit census methods in French Guiana. J. Trop. Ecol. 11, 281-294.

Zimmerman, J.K., Wright, S.J., Calderón, O., Pagan, M.A., Paton, S., 2007. Flowering and fruiting phenologies of seasonal and aseasonal neotropical forests: the role of annual changes in irradiance. J. Trop. Ecol. 23, 231-251. 